\title{
CURRENT DATA ON THE INDONESIAN MILITARY ELITE, APRIL 2008-SEPTEMBER 2013
}

\section{The Editors}

\section{Introduction}

This report identifies the mutasi jabatan, or reshuffles, of key positions within the Indonesian National Defense Forces (Tentara Nasional Indonesia, TNI) headquarters, and includes changes that have taken place within the army's central and regional commands between April 2008 and September 2013. The timeline for this update covers primarily the second term of President Susilo Bambang Yudhoyono's administration.

Two major developments are the focal point of analysis during this period. First, a simultaneous reshuffle of the armed services' chiefs of staff, which took place one month after the reelection of President Yudhoyono. Second, there were three different TNI commanders-in-chief (Panglima TNI) during this time and four of the army's chiefs of staff were replaced.

Overall, Indonesia's military personnel reshuffles during this period indicate a smooth and organized leadership transition from the alumni of the classes of 1976-78 to younger officers from 1980 s classes. In the following sections, we highlight key patterns evident in recent personnel reshuffles and provide an assessment of steps taken to professionalize the military by looking closely at military organizational development. 


\section{Timing and Patterns of Personnel Reshuffles}

Table 1 highlights the timing of Indonesia's military personnel reshuffles during the period of this listing, particularly those involving seventy-three strategic positions within TNI headquarters and army commands, which have had an impact on both central and regional command structures. This report identifies five major waves of personnel turnovers during the past five years-affecting approximately one hundred officers each time, and including some minor reshuffles for a number of key positions. The major events occurred in May and September 2008, May 2010, February 2012, and January 2013. Compared with a 2008 study published by Indonesia's editors, there were only three big waves of personnel moves between September 2005 and March 2008. ${ }^{1}$

The current listing also shows a slight acceleration regarding the pace of generational change within the Indonesian military. As shown below, given the small sizes of the 1976-80 classes, there arose a shortage of high-ranking officers available to occupy positions in military headquarters and several civilian ministries. This condition led to the relatively quick advancement of the 1980s-generation officers. To understand the key patterns of recent personnel reshuffles, this report examines TNI's personnel changes in a chronological manner.

With many senior officers from the 1974 and 1975 classes reaching the mandatory retirement age of 58 in 2009, younger officers from the classes of 1976 to 1980 were introduced into the military's command structure. It was in this context that the personnel changes in 2008 should be understood. The key purpose was to avoid major personnel changes in the military headquarters in the run-up to the legislative and presidential elections in April and July 2009.

With that objective in mind, the military undertook major personnel changes in May and late June 2008 affecting 157 officers. Specifically, the officers holding two strategic posts in the army, namely deputy chief of staff and commander of Army Special Forces Command (Kopassus), were replaced and, significantly, succeeded by President Yudhoyono's brothers-in-law, generals Johannes Suryo Prabowo (Class of 1976) and Pramono Edhie Wibowo (Class of 1980). The army chief Gen. Agustadi Purnomo had developed personal ties with Yudhoyono as they both shared overlapping backgrounds in their military careers. ${ }^{2}$ The personnel changes exerted an impact on the commanders of the regional command (Kodam) as well, including generals Hotmangaradja Pandjaitan (Bali commander), Soenarko (Aceh commander), and Darpito Pudyastungkoro (Jakarta commander). With the ongoing post-conflict reintegration in Aceh an important consideration, the main mission of Maj. Gen. Soenarko was to assist local police to maintain security and order in the province during the 2009 elections.

The military also completed another major reshuffle in September 2008, including three crucial postings. First, TNI commander-in-chief Gen. Djoko Santoso (Class of 1975) appointed two classmates, Maj. Gen. Anshory Tadjudin and Maj. Gen. Abdul Ghofur, as his assistants for military intelligence and logistics affairs, respectively.

\footnotetext{
' See The Editors, "Current Data on the Indonesian Military Elite, September 2005-March 2008," Indonesia 85 (April 2008): 81-121.

${ }^{2}$ Ibid., pp. $86-87$.
} 
Table 1

Military Personnel Reshuffles, 2008-13

\begin{tabular}{|c|c|c|c|c|c|c|c|c|c|}
\hline Year & Month $^{3}$ & $\begin{array}{l}\text { TNI } \\
\text { HQ }\end{array}$ & $\begin{array}{c}\text { Army } \\
\text { HQ }\end{array}$ & Total & Year & Month* & $\begin{array}{l}\text { TNI } \\
\text { HQ }\end{array}$ & $\begin{array}{c}\text { Army } \\
\text { HQ }\end{array}$ & Total \\
\hline 2008 & $\begin{array}{c}\text { April } \\
\text { May } \\
\text { June } \\
\text { July } \\
\text { September } \\
\text { October } \\
\text { November }\end{array}$ & $\begin{array}{l}1 \\
1 \\
1 \\
1 \\
4 \\
0 \\
0\end{array}$ & $\begin{array}{l}0 \\
7 \\
6 \\
0 \\
5 \\
1 \\
2\end{array}$ & $\begin{array}{l}1 \\
8 \\
7 \\
1 \\
9 \\
1 \\
2\end{array}$ & 2011 & $\begin{array}{c}\text { January } \\
\text { February } \\
\text { March } \\
\text { May } \\
\text { June } \\
\text { July } \\
\text { August } \\
\text { September }\end{array}$ & $\begin{array}{l}4 \\
0 \\
2 \\
1 \\
3 \\
2 \\
2 \\
1 \\
\end{array}$ & $\begin{array}{c}2 \\
1 \\
4 \\
12 \\
3 \\
7 \\
1 \\
9 \\
\end{array}$ & $\begin{array}{c}6 \\
1 \\
6 \\
13 \\
6 \\
9 \\
3 \\
10 \\
\end{array}$ \\
\hline 2009 & $\begin{array}{c}\text { May } \\
\text { September } \\
\text { October } \\
\text { November } \\
\text { December } \\
\end{array}$ & $\begin{array}{l}0 \\
1 \\
2 \\
2 \\
2\end{array}$ & $\begin{array}{l}1 \\
0 \\
6 \\
9 \\
3\end{array}$ & $\begin{array}{c}1 \\
1 \\
8 \\
11 \\
5\end{array}$ & 2012 & $\begin{array}{c}\text { October } \\
\text { November } \\
\text { December } \\
\text { February } \\
\text { March } \\
\end{array}$ & $\begin{array}{l}0 \\
0 \\
0 \\
2 \\
0\end{array}$ & $\begin{array}{c}10 \\
3 \\
1 \\
11 \\
1 \\
\end{array}$ & $\begin{array}{c}10 \\
3 \\
1 \\
13 \\
1 \\
\end{array}$ \\
\hline 2010 & $\begin{array}{c}\text { January } \\
\text { February } \\
\text { March } \\
\text { May } \\
\text { June } \\
\text { July } \\
\text { August } \\
\text { September } \\
\text { October } \\
\text { December } \\
\text { Unknown }\end{array}$ & $\begin{array}{l}1 \\
0 \\
1 \\
4 \\
0 \\
0 \\
2 \\
1 \\
3 \\
0 \\
0 \\
\end{array}$ & $\begin{array}{c}5 \\
1 \\
12 \\
14 \\
1 \\
1 \\
1 \\
13 \\
8 \\
1 \\
5 \\
\end{array}$ & $\begin{array}{c}6 \\
1 \\
13 \\
18 \\
1 \\
1 \\
3 \\
14 \\
11 \\
1 \\
5 \\
\end{array}$ & 2013 & $\begin{array}{c}\text { May } \\
\text { June } \\
\text { July } \\
\text { August } \\
\text { September } \\
\text { November } \\
\text { December } \\
\text { Unknown } \\
\text { January } \\
\text { March } \\
\text { April }\end{array}$ & $\begin{array}{l}0 \\
3 \\
0 \\
1 \\
0 \\
0 \\
1 \\
0 \\
3 \\
1 \\
2\end{array}$ & $\begin{array}{l}12 \\
5 \\
9 \\
8 \\
7 \\
1 \\
0 \\
1 \\
2 \\
1 \\
8\end{array}$ & $\begin{array}{c}12 \\
8 \\
9 \\
9 \\
7 \\
1 \\
1 \\
1 \\
5 \\
2 \\
10\end{array}$ \\
\hline
\end{tabular}

Second, Maj. Gen. Hotma Marbun was assigned as the army chief's operational assistant. He served with generals Soenarko and Hotmangaradja in the Army Special Forces Command. All three officers had graduated together from the Military Academy in 1977. His appointment thereby strengthened the position of those in TNI with military skills for special warfare. Third, President Yudhoyono replaced the commander of the Presidential Guards (Paspampres) by promoting Brig. Gen. Marciano Norman (Class of 1978). ${ }^{4}$ Previously, Marciano spent much of his career in

\footnotetext{
${ }^{3}$ Due to incomplete information in some of the official documents reviewed, it is not possible to identify the specific timeline of six reshuffles of personnel. Interviews and online sources were only able to provide information for the year that these reshuffles took place. For the purposes of recording this data, if we were unable to verify the month of the transfer/appointment, then such anomalies would be classified as "Unknown"(five reshuffles in 2010 and another in 2012).

${ }^{4}$ Maj. Gen. Marciano Norman's family background was particularly interesting. He was the son of the late General Norman Sasono, who also served as the presidential guard commander (1965-72) and then Jakarta commander (1977-83). Marciano's career seemingly mirrored that of his father.
} 
the Jakarta regional military command, including a stint as commander of the cavalry battalion and operational assistant to the regional commander.

Having been reelected in October 2009, President Yudhoyono began to plan for the succession of the TNI commander-in-chief to ensure a stable leadership transition in the armed forces. General Djoko Santoso had led the Indonesian military since December 2006 and was almost at the mandatory retirement age. The TNI law required that any candidate for the post of Armed Forces Commander had to be either the incumbent or a former chief of the army, navy, or air force. With that in mind, Yudhoyono concurrently replaced all chiefs of the armed services soon after his reelection. In November 2009, he named Lt. Gen. George Toisutta (Class of 1976) as the army's chief of staff, Air Marshal Imam Sufaat (Class of 1977) as the air force's chief of staff, and Vice Admiral Agus Suhartono (Class of 1978) as the navy's chief of staff. In addition, a month earlier, the military had a new chief of general staff, Air Marshal Edy Harjoko (Class of 1975), who would represent the air force at TNI's high command.

Following his appointment, Gen. Toisutta sought to consolidate his leadership position within the army. Between January and March 2010, he upgraded the rank of his classmates, including Maj. Gen. Burhanudin Amin (commander of Army Strategic Reserve Command, Kostrad), Brig. Gen. Mulhim Asyrof (assistant for army planning), Brig. Gen. Jul Effendi Sjarief (assistant for territorial affairs), and Brig. Gen. Tan Aspan (East Kalimantan commander). Toisutta also appointed generals Muhammad Noer Muis and Hatta Syarifudin to lead the West Sumatra and Maluk commands, respectively. In the following reshuffle, Gen. Toisutta promoted another classmate, Brig. Gen. Ali Yusuf Susanto as his assistant for personnel to assist him in managing personnel changes at the army headquarters.

A third wave of personnel changes came in May 2010, involving a total of 130 officers. This time, Gen. Toisutta showed his commitment to move young officers into first- and second-tier command posts at the army headquarters. He promoted two senior officers from the class of 1978, namely Maj. Gen. Budiman (commander of army education and training command) and Brig. Gen. Leonardus Johan Siegers (West Sumatra commander). Budiman, who previously served as Yudhoyono's presidential military secretary and then Central Java commander, became the first of his class to earn the rank of lieutenant general. This particular reshuffle included the redesignation of Maj. Gen Marciano Norman, who was appointed Jakarta military commander. Replacing him as commander of the Presidential Security Guard was Brig. Gen. Waris (Class of 1981). Previously, Gen. Toisutta had promoted Marciano's classmates, generals Geerhan Lantara (commander of Kostrad's 2nd infantry division) and Tisna Komara (assistant for army security affairs). Both were leading officers in the Army Special Forces Command.

From October 2009 to May 2010, personnel changes not only placed the alumni of the 1976-78 classes in charge of the army's high command, but also highlighted the promotion of officers who graduated in the 1980s. Table 2 highlights the fact that, unlike the 1974 and 1975 classes, with 434 and 304 graduates, respectively, the classes of 1976-78 have fewer alumni, averaging around a hundred officers per class. Accordingly, officers from the 1980-84 classes were promoted to fill the existing positions within the defense and military establishments. Besides Maj. Gen. Pramono Edhie Wibowo (appointed to the prestigious West Java command in October 2009), the 
group of 1980s academy graduates to hold high-ranking positions was represented by generals Lodewijk Freidrich Paulus (Kopassus commander), Moeldoko (commander of the newly established West Kalimantan command), Gatot Nurmantyo (governor of military academy), Ibrahim Saleh (commander of army intelligence center), and Nugroho Widyotomo (deputy commander of Kopassus).

Table 2

Military Academy Graduates, 1974-90

\begin{tabular}{|c|c|}
\hline Year $^{*}$ & $\begin{array}{c}\text { Number of } \\
\text { Officers }\end{array}$ \\
\hline 1974 & 434 \\
1975 & 303 \\
1976 & 85 \\
1977 & 79 \\
1978 & 93 \\
1980 & 102 \\
1981 & 153 \\
1982 & 83 \\
1983 & 187 \\
1984 & 240 \\
1985 & 253 \\
1986 & 213 \\
1987 & 263 \\
1988 & 536 \\
1989 & 258 \\
1990 & 267 \\
\hline
\end{tabular}

* In 1979, there was no intake for the National Military Academy (Akademi Militer Nasional, AMN).

Gen. Djoko Santoso was scheduled to retire in September 2010. Since the introduction of the TNI law in 2004, the primary benchmark for measuring military reform, both chiefs of the air force and army had served as the commander-in-chief. Continuing the practice of leadership rotation among the armed services, President Yudhoyono then nominated the navy's newly appointed chief of staff, Admiral Agus Suhartono, as TNI's top commander. His tour of duty included appointments as the navy chief's operational assistant, Western Fleet commander, and inspector general at the defense ministry. Given his professional credentials, the Indonesian parliament 
unanimously agreed to accept Suhartono's nomination. On September 28, 2010, President Yudhoyono officially installed Admiral Suhartono as the TNI chief.

Besides the succession of the commander-in-chief, the military undertook a personnel reshuffle in September 2010, reflecting both of Yudhoyono's preferences. To replace Lt. Gen. Burhanudin Amin as Kostrad's top commander, Yudhoyono appointed Pramono Edhie Wibowo, thereby paving the way for him to become a legitimate candidate to fill the position of army chief after Gen. Toisutta. In turn, Toisutta selected Maj. Gen. Moeldoko to take over the prestigious West Java command. As the top graduate in the class of 1981, Moeldoko shared a rare distinction with Yudhoyono, who was the top graduate in the class of 1973. The personnel reshuffle touched upon other strategic posts a well, involving generals Leonard (army chief's assistant for security affairs), Geerhan Lantara (West Kalimantan commander), Erfi Triassunu (Papua commander), Gatot Nurmanyo (East Java commander), and Muhamad Munir (commander of Kostrad's 2nd infantry division). While Geerhan and Erfi were classmates in the Military Academy, Leonard, Gatot, and Munir graduated in 1981, 1982, and 1983, respectively.

Meanwhile, Admiral Suhartono began to consolidate his leadership within the armed forces. A week after his installation, he handpicked Air Vice Marshal Daryatmo to take charge of matters relating to personnel management. Since the appointment of Air Vice Marshal Mulyanto in 2006, the TNI chief's personnel assistant post had been primarily reserved for an air force two-star general. Suhartono also selected generals Hambali Hanafiah and Azmyn Yusri Nasution as his assistants for military operations and territorial affairs, respectively. A few months prior to the nomination of Suhartono as TNI Commander, the assistant for military logistics, Maj. Gen. Hari Krisnomo, and assistant for intelligence affairs, Maj. Gen. Tisna Komara, were appointed to their positions. With the exception of Nasution, all these officers were 1978 academy graduates. In the subsequent reshuffles, Suhartono recruited his trusted classmates, namely admirals Soleman Ponto (head of the military's Strategic Intelligence Body, Badan Intelijen Strategis, BAIS) and Among Margono (TNI chief's assistant for military planning). As key positions in TNI's high command were by now occupied by Suhartono's classmates, his consolidation of leadership was almost completed by early 2011.

Following some minor reshuffles, two waves of personnel changes were evident in March and May 2011. These were noteworthy changes as they involved senior officers with close relationships to President Yudhoyono and essentially laid the groundwork for the coming retirement of Gen. George Toisutta, the army chief of staff. This time, key positions in TNI and army headquarters were reshuffled, including three-star general posts, presidential guards commander, army chief's assistants, and three regional commanders.

Firstly, Air Marshal Edy Harjoko, who had served as part of TNI's top leadership (as TNI's chief of general staff), reached his retirement age and was replaced by Yudhoyono's brother-in-law, Lt. Gen. Johannes Suryo Prabowo, the army's deputy chief of staff. With this promotion, Suryo Prabowo would channel the army's support to bolster Admiral Suhartono's leadership. In turn, Lt. Gen. Budiman was selected to take over the post of army deputy chief. Budiman, who was the top graduate of the 1978 class, had been among Yudhoyono's trusted generals following his past posting 
as the presidential military secretary. This move then led to the promotion of Maj. Gen. Marciano Norman, another Yudhoyono's loyalist, to lieutenant general and commander of the army education and training command. As three-star generals, both Budiman and Marciano were in line to become candidates eligible to replace Gen. Toisutta, who would retire soon.

Secondly, in replacing Lt. Gen. Marciano Norman, Gen. Toisutta selected Yudhoyono's presidential guards commander, Maj. Gen. Waris, to take over the strategic Jakarta command, while promoting Brig. Gen. Agus Sutomo (Class of 1984) to command the presidential guards. In the past, the latter had directly served Yudhoyono as the commander of Group A of the presidential guards before being deputized to become Kopassus commander. ${ }^{5} \mathrm{Col}$. Doni Munardo was then appointed to fill Agus's previous post, thereby making him the first officer of the 1985 class to earn the rank of brigadier general. Previously, Doni had replaced his senior as the Group A commander and West Java sub-regional commander, positions that had been held by Lt. Gen. Pramono Edhie Wibowo.

Thirdly, Gen. Toisutta made personnel changes in the army's central and regional commands. He promoted generals Thomas Edy Widagdo (Class of 1978), Hardiono Saroso (Class of 1981), and Sonny Widjaya (Class of 1982) to the rank of major general; each was respectively given new postings as the army chief's assistants for territorial affairs, operations, and logistics. Similarly, Brig. Gen. Ibrahim Saleh (Class of 1983), who shared the same birthplace in Makassar with Gen. Toisutta, was promoted and became his assistant for security affairs. Toisutta also appointed Maj. Gen. Suwarno Widjonarko (Class of 1980) and Maj. Gen. Leonard to lead the South Sumatra and Bali commands, respectively.

Meanwhile, President Yudhoyono announced that Gen. Toisutta, having reached the mandatory retirement age of fifty-eight, would leave his position on July 1, 2011. At that time, there were seven lieutenant generals who were eligible to take up the army's top position and replace Toisutta, given their rank. However, Toisutta submitted the names of only three candidates to Yudhoyono, namely, Lt. Gen. Pramono Edhie, Lt. Gen. Budiman, and Lt. Gen. Marciano Norman. ${ }^{6}$ All three candidates had close associations with the president. Although Budiman and Marciano graduated in 1978, Pramono was the most senior officer in terms of age. During his tour of duty he had spent many of his years with the Army Special Forces Command before being promoted to take charge of the West Java regional command, followed by a stint as the commander of Army Strategic Command. Since the selection of service chiefs is a presidential prerogative, Yudhoyono eventually announced that Gen. Toisutta's successor as the army chief would be Pramono Edhie Wibowo. Gen. Pramono officially succeeded Gen. Toisutta on July 7, 2011.

\footnotetext{
${ }^{5}$ The Paspampres consists of three groups: Group A protects the president, Group B is responsible for protecting the vice president, and Group C takes care of the security arrangements for visiting VIPs and VVIPs.

${ }^{6}$ Like Gen. Toisutta, the other four lieutenant generals would soon retire. These generals were Syarifudin Tippe (Rector of Indonesian Defense University), Johannes Suryo Prabowo (TNI chief of general staff), Muhamad Noer Muis (former military inspector general), and Hotmangaradja Pandjaitan (secretary at the coordinating ministry of politics, law, and security affairs).
} 
From July to October 2011, both Gen. Pramono and Admiral Suhartono oversaw personnel reshuffles in military headquarters. Having promoted Air Vice Marshal Daryatmo to head the National Search and Rescue Agency (Badan SAR Nasional, Basarnas), Suhartono selected Air Vice Marshal Bambang Wahyudi (Class of 1978) to manage the turnover of military personnel. He recruited Rear Admiral Slamet Yulistyono and Maj. Gen. Langgeng Sulistyono to be his assistants for military electronic communications and territorial affairs, respectively. Both were 1980 academy graduates. The pattern of leadership consolidation through the promotion of fellow classmates was again evident when Gen. Pramono promoted generals Subekti (army chief's assistant for planning), Zahari Siregar (Aceh commander), and Erwin Hudawi Lubis (West Kalimantan commander). Pramono also moved young officers to serve in the army's command structure. Out of the 1981 class, he handpicked Brig. Gen. Wisnu Bawa Tenaya as Kopassus commander, while transferring Maj. Gen. Lodewijk Freidrich Paulus to the West Sumatra command. Having appointed Lt. Gen. Azmyn Yusri Nasution as Kostrad commander, Pramono elevated the rank of Brig. Gen. Harry Purdianto (Kostrad's 1st division commander) and Brig. Gen. M. Ridwan (Kostrad's 2nd division commander) to major generals.

Moreover, personnel turnovers during this period highlighted two important appointments. First, Maj. Gen. Moeldoko was seconded to the head of the National Resilience Institute (Lembaga Ketahanan Nasional, Lemhannas). The transfer was significant given Moeldoko's excellent military career and the general expectation that he was earmarked to become the army's top leader in the future. Despite the speculation surrounding his transfer, ${ }^{7}$ Moeldoko's new posting allowed him the opportunity to enhance his professional networks with both national and regional leaders, who regularly took leadership courses in Lemhannas. Second, Lt. Gen. Marciano Norman was selected by President Yudhoyono to head the National Intelligence Agency (Badan Intelijen Negara, BIN). This appointment took place soon after the Indonesian parliament had approved the national intelligence bill in early October 2011. Marciano, however, was nominated not only because he was among Yudhoyono's most trusted generals, but because his previous tour of duty as the director of strategic assessment at the defense ministry provided him with the relevant skill sets to undertake his responsibilities.

Throughout 2012, there were multiple personnel appointments on fifteen occasions within the military establishment. The largest wave came in February 2012, involving 115 officers. This time, Gen. Pramono promoted Maj. Gen. Muhamad Munir to become Kostrad commander, thereby making him the first officer of the 1983 class to earn a three-star rank. Previously, Munir had replaced Lt. Gen. Moeldoko as West Java commander. Pramono also introduced new assistants for army planning and security affairs by appointing Brig. Gen. Dicky Wainal Usman (Class of 1980) and Maj. Gen. Eko Wiratmoko (Class of 1982), respectively. In addition, personnel reshuffling touched upon four regional commands, including Papua, West Java, East Kalimantan,

\footnotetext{
${ }^{7}$ Speculation was rife that Moeldoko's new posting was likely to pave the way for Maj. Gen. Muhamad Munir, a former Yudhoyono adjutant, to gain experience as the West Java commander. Another explanation for Moeldoko's transfer was his alleged involvement in the repression of the Ahmadiyya religious minority group while he was serving as West Java commander. However, in the absence of accurate evidence or disclosures following investigations, it remains difficult to prove such allegations.
} 
and South Sumatra. For these posts, Gen. Pramono handpicked generals Erwin Syafitri (Class of 1982), Sonny Widjaya, Subekti, and Nugroho Widyotomo (Class of 1984).

Another reshuffle took place in May 2012. This reshuffle fulfilled TNI's 2010 plan to upgrade the rank of commanding officers for several army sub-regional commands (Korem) to the rank of brigadier general. The plan was devised partly to recognize that the strategic locations of these Korem for defense purposes required the presence of a one-star general in many cases. Targeting specifically regions with borders with close proximity to Indonesia's neighbors, Gen. Pramono handpicked new commanders to lead nine sub-regional commands. The appointments were as follows: Brig. Gen. Teguh Rahardjo became Korem 031 commander, in Pekanbaru; Brig. Gen. Deni K. Irawan became Korem 033 commander, in Tanjung Pinang; Brig. Gen. Widjaya was installed as commander of Korem 072, in Yogyakarta; Col. Gadang Pambudi moved to Samarinda as Korem 091 commander, with promotion to brigadier general; Col. Johny L. Tobing was promoted to command Korem 131, in Manado; Brig. Gen. Ferdinand Setiawan was transferred to lead Korem 161, in Kupang; Brig. Gen. Pandji Suko Hari Yudho was appointed as Korem 171, in West Papua; Col. F. X. Bangun Pratiknyo was promoted to one-star general and became Korem 173 commander, in Central Papua; and Col. Edy Rahmayadi was promoted to brigadier general and given command of Korem 174, in South Papua. These officers were drawn primarily from the cohort of academy graduates from the 1983-85 classes.

The reshuffles in the second half of 2012 would highlight two important developments. First, the military had a new inspector general and chief of general staff. As Air Marshal Sukirno and Lt. Gen. Johannes Suryo Prabowo were about to retire, Admiral Suhartono subsequently promoted Maj. Gen. Geerhan Lantara and handpicked Air Marshal Daryatmo to fill the two posts. These appointments showed the emerging practice of balancing the representation of each armed service at the TNI high command. Second, both the air force and navy had new chiefs of staff. In December 2012, President Yudhoyono nominated Air Marshal Ida Bagus Putu Dunia and Vice Admiral Marsetio to take command of the two services, respectively. Both were the top graduates of the 1981 class, and their nomination highlighted a generational transition in the navy and air force's top leadership.

While Indonesia was preparing for the national elections in 2014, the military then undertook a fifth major wave of personnel changes in January 2013. This was another significant reshuffle as it involved top graduates of the Military Academy. In replacing Air Marshal Eris Heryanto, Lt. Gen. Budiman became the secretary general of the defense ministry. In the past, Budiman had served in the ministry as the director of strategic policy planning. In turn, Lt. Gen. Moeldoko returned to the army and became Gen. Pramono's deputy chief. This new posting enhanced Moeldoko's prospects to succeed Pramono, who would soon complete his term in the military. In addition, Maj. Gen. Ediwan Prabowo became East Java commander. Ediwan, who was the top graduate of the 1984 class, previously headed the Defense Facilities Agency (Badan Pratanahan, Baranahan) at the defense ministry.

Gen. Pramono was scheduled to retire on May 5, 2013. Although he applied for early retirement in mid-March, President Yudhoyono wanted him to stay on until plans for leadership succession within the armed forces were finalized. In the meantime, Pramono submitted to Yudhoyono the names of seven lieutenant generals 
who were normatively eligible for the post of army chief. They were: Lt. Gen. Budiman, Lt. Gen. Geerhan Lantara, Lt. Gen. Langgeng Sulistyono (secretary of Coordinating Ministry of Political, Legal, and Security Affairs), Lt. Gen. Waris (secretary general of the National Security Council [Badan Pertahanan Nasional Indonesia, Wantannas]), Lt. Gen. Moeldoko, Lt. Gen. Gatot Nurmantyo (commander of army education and training command), and Lt. Gen. Muhamad Munir. Although these individuals were all credible candidates, it was rumored that Yudhoyono favored Lt. Gen. Budiman. Pramono, though, seemed to have prevailed with his nomination of Moeldoko, who in reality seemed the better prospect in terms of finding the balance between generational change and operational experience. In addition to his achievement as the top graduate in 1981, Moeldoko served twice as an army regional commander (West Kalimantan and West Java) and was army deputy chief at the time of his new appointment. His stint at Lemhannas meant that he had access to wideranging political and bureaucratic networks. In tandem with the appointment of a new finance minister, President Yudhoyono announced that Lt. Gen. Moeldoko would replace Gen. Pramono.

On May 23, 2013, Gen. Moeldoko was officially installed as the army chief of staff. Along with leadership succession at the highest echelon, the army reshuffles resulted in the following officers holding these strategic posts: Lt. Gen. Muhamad Munir became the army's deputy chief, Lt. Gen. Gatot Nurmantyo was deployed to take command of Kostrad, and Maj. Gen. Lodewijk Freidrich Paulus was promoted to lieutenant general and commander of the army education and training command.

The climax of Admiral Suhartono's TNI leadership came three months later. After fifty-eight years of military service, Suhartono was scheduled to retire in August 2013. Since 2004, all chiefs of the air force, army, and navy had enjoyed a stint as Armed Forces Commander. The conclusion of Admiral Suhartono's term thereby completed the first round of leadership rotations among the three services. Theoretically, the incumbent chiefs of each service were now legitimate candidates for the post of TNI chief.

As noted earlier, President Yudhoyono had planned for the succession of the military's top commander. The nomination of the new army chief, in turn, had laid the groundwork for the coming succession of the military's top leadership. Yudhoyono then nominated Gen. Moeldoko as Admiral Suhartono's successor. As had been true when Suhartono was nominated in 2010, the process of winning parliamentary approval for Moeldoko went smoothly due to the officer's excellent military career and clean record on corruption. During the parliament's fit-and-proper test session, Gen. Moeldoko presented his vision on improving the military manpower policy and arms modernization, while stressing his commitment to steer the military away from political activities. Following legislative approval on Moeldoko's nomination, President Yudhoyono then handpicked Lt. Gen. Budiman to take command of the army.

Gen. Moeldoko was officially sworn in as TNI chief on September 4, 2013. His appointment effectively underscored a leadership transfer from the 1970s to $1980 \mathrm{~s}$ generation of officers in the Indonesian military. Also interesting was the educational background of the new TNI chief and the armed services' chiefs; all of them were top graduates of the Military Academy. Their progression through the ranks and 
socialization during the Reformasi era will have prepared them to contribute to military's development as a professional force in the future. The question remains whether a sustained period of poor political conditions in the country will, over time, lead to backsliding. Despite a greater orientation to their professional tasks, national stability still remains an abiding concern for Indonesia's military officers. Key tasks in the short term remain the need to ensure a stable transition in national leadership during the run-up to legislative and presidential elections in 2014. During the elections, General Moeldoko reiterated TNI's commitment to political neutrality and ordered all TNI personnel to refrain from taking sides. Approximately 31,370 TNI personnel were deployed to secure the presidential election, held on July 9, 2014.

Yet the issue of TNI neutrality during the presidential campaign became a source of controversy between President Yudhoyono and the leading generals in the army. During a June 2 meeting at the Ministry of Defense headquarters specifically convened to discuss the neutrality of TNI during the presidential election, President Yudhoyono issued a strong warning directed at the high-ranking military officers present on the need for the army to remain neutral in politics and not to behave in a manner that would contravene Article 2 (d) of Law No. 34/2004 on the TNI.

In the run-up to the presidential elections, numerous news reports surfaced alleging that a babinsa (village non-commissioned officer) had conducted surveys and asked voters about their preferences regarding a particular presidential candidate. Following an investigation by army headquarters, disciplinary action was sanctioned by Gen. Budiman against the soldier who had committed an election violation in Jakarta, and against his commanding officer. ${ }^{8}$ Apparently a complaint was received from a resident living in a predominantly Chinese neighborhood in Central Jakarta who had been visited by a man on May 31 claiming to be a babinsa who said he had been assigned to verify the data of eligible voters in the neighborhood. ${ }^{9}$ Later it was claimed that the babinsa was registering those locals intending to vote for the Gerindra Party presidential candidate, Prabowo Subianto, a former Army Special Forces commander.

Verifying such claims is difficult, particularly in the wake of rumors that such accusations were specifically orchestrated to discredit Prabowo's candidacy. After all, Gen. Moeldoko and Gen. Budiman's links to both Indonesian Democratic Party of Struggle's (PDI-P) presidential candidate Joko "Jokowi" Widodo and Megawati suggested that the military elite invariably had their own preferences, despite restrained enthusiasm among the young generation of officers for a Prabowo presidency, no doubt attracted by his persona and image as a strong president. The image of Jokowi as a weak commander-in-chief was undoubtedly reinforced during the presidential debates by his inability to project a strong image of himself as a

\footnotetext{
${ }^{8}$ The army reprimanded Gambir military district commander Capt. Inf. Saliman for negligence and barred him from promotion for six months. First Corporal Rusfandi was sentenced to twenty-one days in the army detention center and was made ineligible for promotion for the next eighteen months. See: "Slap on the Wrist for Babinsa Canvasser," The Jakarta Post, June 9, 2014; "Bawaslu to Summon Moeldoko over Alleged TNI Intimidation," The Jakarta Post, June 7, 2014; and Pendata suara dari barak," Tempo, June 15, 2014.

9 "Datangi Rumah ke Rumah, Anggota Babinsa Arahkan Warga Pilih Prabowo," Kompas, June 5, 2014, http: / / nasional.kompas.com/ read/2014/06/05/0957038/Datangi.Rumah.ke.Rumah.Anggota.Babinsa. Arahkan.Warga.Pilih.Prabowo, accessed August 6, 2014.
} 
president who would vigorously defend Indonesia's territorial integrity. Wanting to neutralize any perception that TNI was playing politics, Gen. Moeldoko steadfastly maintained that the Gambir incident was a single, isolated case.

Yet Yudhoyono, whose Democratic Party officially endorsed the Prabowo-Hatta presidential ticket on June 1, refused to be placated by Moeldoko's assurances or Budiman's actions. He sought to confront directly the TNI high command. During a speech at the Commander's Call, ${ }^{10}$ Yudhoyono accused TNI elite of being disloyal to him as the military's supreme commander. Present at the meeting were TNI Commander Gen. Moeldoko, Army Chief of Staff Gen. Budiman, Air Force Chief of Staff Air Chief Marshal Ida Bagus Putu Dunia, and Navy Chief Adm. Marsetio. In his speech, Yudhoyono intimated that there was a suggestion that they, the officers, ought to abandon their president and not listen to him, because he is in "a sinking ship |... It is much better to follow a bright new star." ${ }^{11}$ Yudhoyono apparently was also incensed that Budiman had secretly approached Megawati over the possibility that he could be considered a potential candidate for the vice presidency.

Another source of Yudhoyono's consternation was Gen. Moeldoko, who met with Jokowi in April, prompting rumors within PDI-P circles that his name was being touted as a possible running mate for Jokowi. It was known that PDI-P had considered a military $\operatorname{man}^{12}$ as the running mate for Jokowi before Megawati finally settled the issue by opting for Jusuf Kalla. Moeldoko's vague responses to the rumors further served to reinforce perceptions that he was considering his options. ${ }^{13}$

The odds of Moeldoko being featured on a presidential ticket with Jokowi dissipated rapidly following his appearance for an interview with Channel News Asia on April 15. Nothing that Moeldoko said during the interview was controversial, but a photograph of him wearing an expensive timepiece went viral in Indonesia, sparking a storm of criticism online. He countered his critics by stating that the timepiece was a cheap Chinese fake. Moreover, sources close to Gen. Moeldoko were quick to point fingers and say that the "fake watch" incident was a black campaign (kampanye hitam) orchestrated by supporters of Jusuf Kalla, who was then also vying to become Jokowi's running mate.

Before public disapproval regarding Moeldoko's wristwatch, there was a better than even chance for him to be a vice-presidential candidate on the PDI-P ticket. But

${ }^{10}$ A Commander's Call refers to a meeting when a TNI commander yathers his troops and issues orders to address a particular situation. It is the prerogative of a commander to call for a meeting and such meetings may be conducted at regular intervals. "SBY Dikabarkan Berhentikan KSAD Jenderal Budiman" |SBY Reported to Have Dismissed KSAD General Budiman], Republika Online, July 21, 2014,

http:/ / www.republika.co.id/ berita/ nasional / umum/14/07/21/n92iq3-sby-dikabarkan-berhentikanksad-jenderal-budiman, accessed July 23, 2014.

11 "SBY Slams TNI Role in Election," The Jakarta Post, June 3, 2014. SBY's comment was based on a rumor that Gen. Budiman had referred to the Yudhoyono presidency as a "sinking ship." Budiman, naturally, denied that he had made such a statement.

${ }^{12}$ Gen. Budiman was also one of Jokowi's potential vice president candidates. See: "KSAD Budiman Pantas Jadi Cawapres Jokowi" [KSAD Budiman Could Be Jokowi's VP], Tribunnews.com, April 15, 2014, http:// www.tribunnews.com/ pemilu-2014/2014/04/15/ sosok-ksad-budiman-pantas-jadi-cawapres-jokowi, accessed I uly 23, 2014.

13 "Jokowi Meets Moeldoko as Speculation Mounts," TheJakartapost.com, April 4, 2014. http:/ / www.the jakartapost.com/news / 2014/04/04/ jokowi-meets-moeldoko-speculation-mounts.html, accessed luly 23, 2014. 
afterward, the damage was done. Any further discussion about his personal wealth would have, no doubt, crippled his potential candidacy in any event. ${ }^{14}$ The fact that high-ranking officials lead luxurious lifestyles while millions of Indonesians live in poverty is a particularly sensitive issue.

The issue of TNI's neutrality was once again brought to the forefront following a bitterly contested presidential election won by Jokowi and Jusuf Kalla. Following the decision by Yudhoyono's Democratic Party to support the Prabowo-Hatta ticket, there was real concern within the Jokowi camp that this was an implicit signal to the military rank and file to influence election outcomes to favor Prabowo. To counter such a possibility, Jokowi's key campaign strategist, retired Gen. Luhut Pandjaitan, deployed five hundred retired Special Forces officers (drawn from the ranks of lieutenant to major) to deter attempts by babinsa to affect voting patterns in favor of Prabowo. These officers fanned out to various parts of the archipelago, visiting babinsa and reminding them of their responsibility to remain neutral in the presidential election.

There is little doubt that Gen. Budiman's overtures to Megawati were the trigger for his dismissal, although the official line from TNI was that the decision to replace Budiman was made three months earlier. ${ }^{15}$ The symbolism evident in the overtly political nature of Budiman's dismissal could not have been more apparent, considering that it was made on the same day the General Elections Commission (Komisi Pemilihan Umum, KPU) announced the final tally of the presidential election. Gen. Budiman was due to retire in September 2014 anyway, therefore, over and above political expediency, there was actually no reason to replace him in July. Considering the frosty relationship between Yudhoyono and Megawati since the former announced his presidential candidacy in June 2004, Yudhoyono would have been livid that his Army Chief of Staff had met with Megawati without informing him. Moeldoko had also forged links with Megawati. Yet, Yudhoyono did not opt to discipline him severely, as Moeldoko kept his distance from Megawati and Jokowi during the election and post-election period.

Three names of possible successors to Gen. Budiman were proposed by Gen. Moeldoko: Army Strategic Reserve Command (Kostrad) commander Lt. Gen. Gatot Nurmantyo; Deputy Army Chief of Staff Lt. Gen. M. Munir, and Secretary-General of the National Defense Council (Watannas) Lt. Gen. Waris. On July 21, 2014, Lt. Gen Gatot Nurmantyo was officially installed as the new Army Chief of Staff. ${ }^{10}$

\footnotetext{
${ }^{14}$ For more information on Moeldoko's wealth, see: "Ini daftar lengkap kekayaan Jenderal Moeldoko," Tempo, August 22, 2013.

15 "Inilah Penyebab KSAD Budiman Diberhentikan Mendadak" [These Are the Reasons for KSAD Budiman's Sudden Dismissal], Warta Kota, July 21, 2014, http: / / wartakota.tribunnews.com / 2014/07/21 / inilah-penyebab-kasad-jenderal-budiman-digantimendadak, accessed July 23, 2014.

"Kontroversi Pencopotan KSAD [Budiman]" [Controversy on KSAD Budiman's Dismissal], Vivanews, July 23, 2014, http: / / fokus.news.viva.co.id/ news/read/523796-kontroversi-pencopotan-ksad, accessed on July $23,2014$.

It' See: Keppres No 36/ TNI/ 2014, dated July 21, 2014.
} 
Table 3

Academy Class Turnover in Strategic Positions

(April 2008-September 2013)

\begin{tabular}{|l|r|r|}
\hline & \multicolumn{2}{|c|}{$\begin{array}{c}\text { Personnel } \\
\text { Changes }\end{array}$} \\
\hline Upward & 196 & $64.9 \%$ \\
Parallel & 49 & $16.2 \%$ \\
Backward & 52 & $17.2 \%$ \\
Unknown & 5 & $1.7 \%$ \\
\hline Total & 302 & $100 \%$ \\
\hline
\end{tabular}

\section{Academy Class Turnover}

Overall, the 2013 reshuffles highlight a generational change within the Indonesian military. However, as is evident in Table 3, only 65 percent of all personnel turnovers affecting strategic positions over the past five years involved cases of younger officers replacing their seniors. That figure shows only slightly more mobility for younger officers than did measurements in the study produced by The Editors in 2008, which indicated that fewer than 63 percent of personnel postings reflected the upward progression of young officers. ${ }^{17}$ With upward promotions staying below 65 percent of all turnovers, the evidence suggests that the military remains bogged down by logjams in personnel management due to a number of structural factors, including the introduction of a mandatory retirement age of fifty-eight and the prevalence of a large number of academy graduates. Following the abolishment of socio-political posts and the end of a major insurgency in Aceh, the number of strategic positions has significantly decreased. The shortage of posts thereby explains the high frequency of personnel turnover in the past five years, a rate of turnover accelerated to ensure that military officers could be rotated rapidly through existing posts within the military and defense establishments.

\section{Academy Class Distribution}

Table 4 shows the distribution of officers according to their academy class. The nature of the generational transition from April 2008 to September 2013 can be observed by examining the way the domination of key positions shifted from the Classes of 1974-75 to the Classes of the 1980s. The latter currently occupies forty-five of seventy-three strategic positions in this listing, constituting about 62 percent of the

17 "Current Data on the Indonesian Military Elite, September 2005-March 2008," p. 88. 
total. At army headquarters, the dominance of this relatively new cohort is even more obvious; the Classes of the 1980s represent 94 percent of the total.

Table 4

Academy Class Distribution in TNI and Army Headquarters

\begin{tabular}{|c|c|c|c|c|c|c|}
\hline \multirow[b]{2}{*}{ Year* } & \multicolumn{2}{|c|}{ December 2009} & \multicolumn{2}{|c|}{ December 2011} & \multicolumn{2}{|c|}{ September 2013} \\
\hline & TNI HQ & Army HQ & TNI HQ & Army HQ & TNI HQ & $\begin{array}{c}\text { Army } \\
\text { HQ }\end{array}$ \\
\hline 1974 & 1 & 6 & - & - & - & - \\
\hline 1975 & 7 & 7 & 1 & - & - & - \\
\hline 1976 & 3 & 8 & 1 & 3 & 一 & - \\
\hline 1977 & 2 & 7 & 2 & 3 & 一 & - \\
\hline 1978 & 1 & 6 & 8 & 6 & 5 & 1 \\
\hline 1980 & 1 & 1 & 2 & 8 & 4 & 7 \\
\hline 1981 & 1 & 4 & 一 & 16 & 3 & 12 \\
\hline 1982 & 一 & 1 & 1 & 8 & 2 & 6 \\
\hline 1983 & 一 & 1 & 2 & 6 & 2 & 12 \\
\hline 1984 & - & - & 2 & 2 & - & 6 \\
\hline 1985 & - & 一 & - & 1 & 1 & 4 \\
\hline 1986 & - & - & - & - & 一 & 2 \\
\hline 1987 & - & 一 & - & - & 1 & 1 \\
\hline 1988 & - & - & - & - & - & 1 \\
\hline Unknown & 3 & 13 & - & 1 & 1 & 2 \\
\hline
\end{tabular}

* In 1979, there was no intake for the National Military Academy (Akademi Militer Nasional, AMN).

Table 5, on the next page, highlights that the Classes of 1980-84 had essentially taken over all high-ranking officer positions at the army regional commands by September 2013. Gen. Moeldoko's classmates, for instance, had taken command of four of thirteen Kodams, including Aceh, Bali, South Sumatra, and West Sumatra. The current distribution of academy classes at the regional command level will not last long, as the remaining senior officers of the 1978 class will reach retirement age soon after the conclusion of national elections in 2014. Such a situation would moderately ease the logjam, easing the way for officers from the classes of 1985-88, the majority of whom serve as colonels at the sub-regional commands (Korem), to gain promotions. Given the sizes of their classes, which averaged around 250 graduates per class, the 
bulk of these officers-with the exception of a few high flyers-face grim prospects for promotion.

Table 5

Academy Class Distribution in Regional Military Commands (Kodam)

\begin{tabular}{|c|c|c|}
\hline \multirow{2}{*}{ Year } & \multicolumn{2}{|c|}{ September 2013 } \\
\cline { 2 - 3 } & Commander & Chief of Staff \\
\hline 1980 & 3 & - \\
1981 & 4 & 5 \\
1982 & 2 & 3 \\
1983 & 2 & 2 \\
1984 & 2 & - \\
1985 & - & 2 \\
1986 & - & 1 \\
\hline
\end{tabular}

\section{Policy Innovations and Organizational Development}

From 2009 to 2013, TNI leadership's main focus in an era during which "professionalism" has been, and remains, the buzz word, and the strategic environment no longer appears benign, given the uncertainties posed by a rising China, the pressing challenge is the need to bolster Indonesia's military capabilities. During his fit-and-proper test before the parliamentary members of Commission I overseeing defense and foreign and intelligence affairs, Admiral Agus Suhartono presented his vision regarding the priorities that ought to be set in order to make qualitative improvements in TNI's capabilities. He highlighted four important issues for military reform: first, maintaining military professionalism and political neutrality; second, modernizing the military's weapons systems for deterrence purposes against actual and potential threats; third, promoting cohesion and discipline within the armed forces; and fourth, improving the welfare of soldiers. ${ }^{18}$

During his term as TNI Commander in Chief, Admiral Suhartono was committed to managing the military's organization and structure in order to fashion a military posture that could meet Minimum Essential Force (MEF) planning goals. In pursuit of this objective, military headquarters maintained a zero growth policy on personnel recruitment. It also stressed the importance of a "right-sizing" policy designed to determine and control the size of military units. The purpose of this policy is to ensure that the number of military personnel in each unit is adequate to operate weapon systems or perform the specific tasks of a military unit.

18 "Visi Calon Panglima TNI Agus Suhartono," http://m.news.viva.co.id/ news/read/179111-ini-visicalon-panglima-tni-agus-suhartono, accessed February 15, 2014. 
The military leadership established several new units and revised its organization to enhance TNI's operational effectiveness. In 2012 and 2013, it instituted four new organizations within TNI headquarters. First, it set up the Joint Regional Defense Command (Komando Gabungan Wilayah Pertahanan) I, overseeing the western part of Indonesia. The establishment of this command was mandated by Presidential Regulation No. 10/ 2012 on the Structure and Organization of the TNI. ${ }^{19}$

The establishment of the Information and Documents Administration Office (PPID), on July 2012, followed. This initiative was undertaken in response to Law No. $14 / 2008$ on the transparency of public information. The primary responsibilities of this new unit are to ensure a degree of transparency within the military headquarters, preserve and provide access to military information, provide public information accurately, develop information and documentary systems within TNI to classify information or documents, and provide an annual report on information services.

Third, the military opened an education and training department under the TNI Peacekeeping Center (Pusat Misi Pemeliharaan Perdamaian) in December 2011. The key function of the center is to plan and train military personnel or units for overseas peacekeeping operations.

Fourth was the establishment of the Center for International Cooperation (Pusat Kerjasama Internasional) in July 2013. The center manages and coordinates all activities related to the military's cooperative engagements and exchanges with foreign countries. ${ }^{20}$

At army headquarters, there are five new units. First, a new District Military Command (Kodim) 1714 was formed to oversee Puncak Jaya, Papua, in January 2013. The aim of this new Kodim is to reinforce security and stability in that area. ${ }^{21}$ Second, Kodim 0509 was formed, a unit responsible for overseeing Bekasi, which includes a total of thirteen military sub-district units. ${ }^{22}$ The army has also established three new raider battalions under the command of West Kalimantan regional command. The key mission of these units is to enhance the military capabilities for rapid deployment in the region. ${ }^{23}$

At naval headquarters, there were five key organizational developments. First was the establishment of a naval base in Meloguane, North Sulawesi, on October 2011. This new base has responsibility for safeguarding Indonesia's maritime border with the Philippines against unlawful cross-border activities. ${ }^{24}$ Second, a naval base in Morotai

\footnotetext{
19 "Pemerintah Bahas Rencana Pembentukan Kogabwilhan," http: / / www.setkab.go.id/mobile/ berita8665-pemerintah-bahas-rencana-pembentukan-kogabwilhan.html, accessed February 15, 2014.

20 "Panglima TNI Resmikan Puskersin TNI," http:/ / www.tni.mil.id/ view-53156-panglima-tni-resmikanpuskersin-tni.html, accessed March 15, 2014.

21 "Kodim 1714/Puncak Jaya Diresmikan," http:/ / www.tni.mil.id/ view-44296-kodim-1714puncak-jayadiresmikan.html, accessed March 15, 2014.

${ }^{22}$ See "Kodim 0509/Kabupaten Bekasi Dibentuk," Kompas, February 6, 2013, http:/ / megapolitan.kompas. $\mathrm{com} / \mathrm{read} / 2013 / 02 / 06 / 1022569 /$ Kodim.0509Kabupaten.Bekasi.Dibentuk, accessed August 6, 2014.

23 "Kasad resmikan tiga batalyon raider baru," http:/ / www.antarajawabarat.com/lihat/ berita/45096/ kasad-resmikan-tiga-batalyon-raider-baru, accessed March 15, 2014.

24 "Pangarmatim Resmikan Pangkalan TNI AL Melonguane," http: / / www.tni.mil.id/view-29407pangarmatim-resmikan-pangkalan-tni-al-melonguane.html, accessed March 15, 2014.
} 
Island, North Maluku, was officially opened in October $2011 .^{25}$ Third, a new marine battalion was formed and stationed on Setoko Island, Riau. With this new unit, the navy seeks to improve its ability to tackle various threats in border areas. ${ }^{26}$

At the air force headquarters, four new units were created. First, new radar stations in Merauke, Timika, and Saumlaki were deployed. ${ }^{27}$ With these new radar stations, the military has improved its surveillance capabilities to monitor all flights navigating through eastern Indonesian airspace. ${ }^{28}$ Second, a maintenance unit based at Husein Sastranegara airbase, in Bandung, was established. This new unit has responsibility for the maintenance of the military's air cargo aircraft, including CN 235-100/200M, Boeing 737-200/400, and C-295..$^{29}$

The Indonesian military has been concerned with arms procurement. Over the last few years, its leadership has authorized the purchase of a number of new weapons systems for the army, navy, and air force.$^{30}$ From 2010 to 2013, arms acquisitions for the army included eleven BMP-2 infantry fighting vehicles, plus, in the Armored Personnel Carrier category, fourteen APR-1 units, 150 Anoa units, twenty-two Black Fox units, forty LAV-150 Commando units, thirty-two VAB-VTT units, one Barracuda, and one Caspir. In the Artillery category, army acquisitions included eighty Mortar UBM 52 units and nine Multiple Launched Rocket NDL-40 units. In the Anti-Tank category, there was an addition of one hundred and two Mi-17V5 Hip H units, three Bo-105 units, and two EC120B Colibri units. In the Army Air Defense category, there was an addition of forty-two Surface-to-Air Missiles (RBS-70), two Surface-to-Air Missile Kobras, a Surface-to-Air Missile TD 200-B, a Surface-to-Air Missile MANPAD QW-3, and a Towed Guns $23 \mathrm{~mm}$ Giant Bow. In the Armored Recovery Vehicle category, there was an addition of two AMX-13 units, six AMX-VCI units, tree Brem-2 units, and a T55. In the Vehicle Launched Bridge category, the military acquired ten AMX-13 units, a Leguan, and two Stormer units.

25 "Pangarmatim Resmikan Pangkalan TNI AL Melonguane," http:/ / www.tnial.mil.id/ News / Seremonial / tabid/79/articleType/ArticleView/articleld/7326/ pangarmatim-resmikan-lanalmorotai.aspx, accessed March 15, 2014.

26 "TNI al bentuk batalyon korps marinir di pulau wilayah perbatasan," http:/ / www.tnial.mil.id/tabid/ 79/ articleType/ArticleView/articleId/ 13669/ Default.aspx\#\%20target=, accessed March 15, 2014.

27 "Kasau Resmikan Satrad 244," http: / / www.tni.mil.id/ view-25427-kasau-resmikan-satrad-244.html, accessed on March 15, 2014.

28 "Satuan Radar Timika diresmikan," http: / / www.antaranews.com/ berita/ 299860/ satuan-radar-timikadiresmikan, accessed March 15, 2014.

29 “Komadan Koharmatau Resmikan Sathar 14," http:/ / www.tni.mil.id/ view-50918-komadankoharmatau-resmikan-sathar-14.html, accessed March 15, 2014.

${ }^{30}$ For figures on TNI arms acquisitions, 2010-13, see: International Institute of Strategic Studies, The Military Balance 2010 (London: Routledge, 2010), pp. 405-8; International Institute of Strategic Studies, The Military Balance 2011 (London: Routledge, 2011), pp. 242-45; International Institute of Strategic Studies, The Military Balance 2012 (London: Routledge, 2012), pp. 248-51; and International Institute of Strategic Studies, The Military Balance 2013 (London: Routledge, 2013), pp. 302-5. 
Army's Arms Acquistions, 2010-13

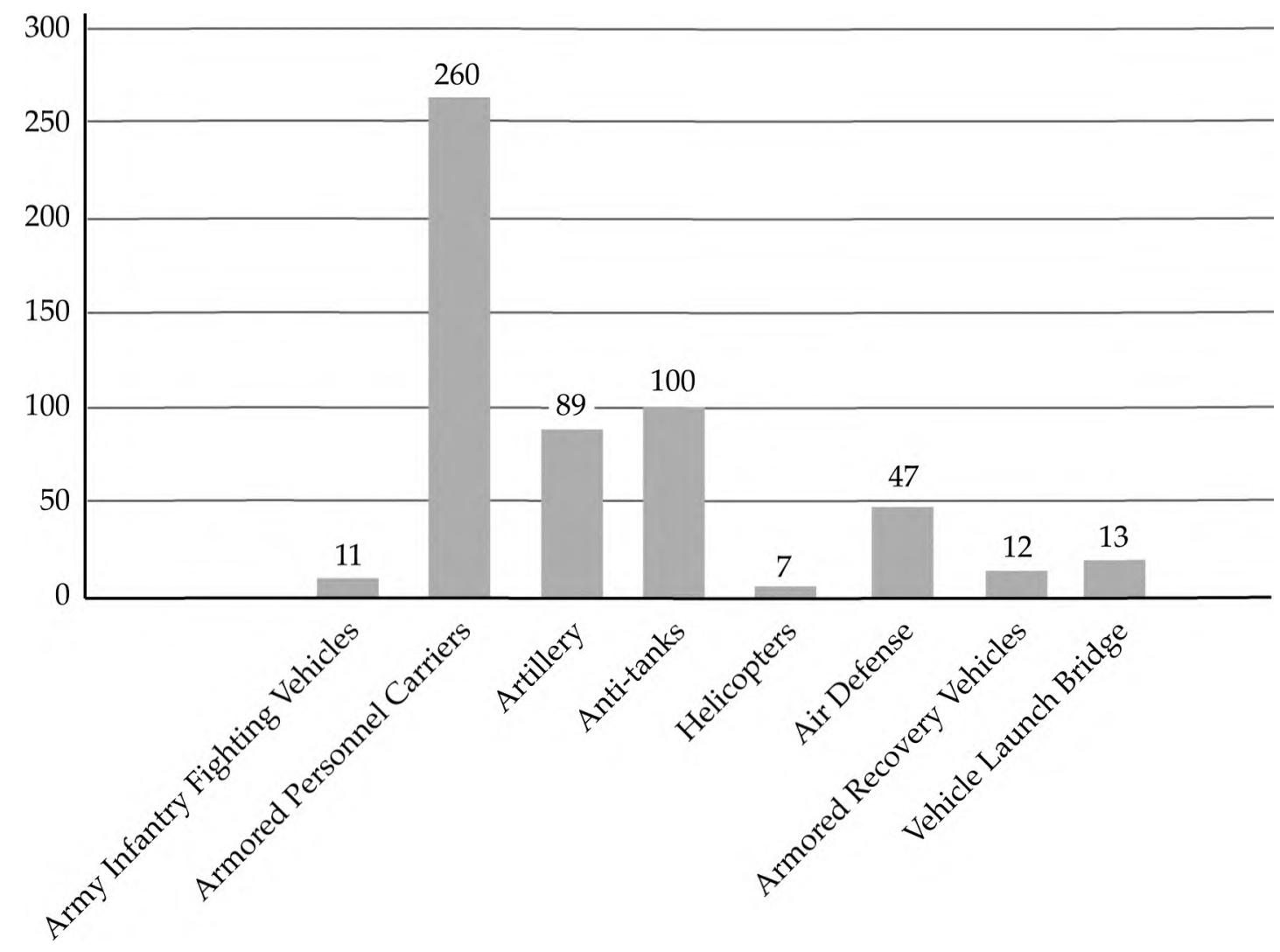

For the navy (see next page), within the Principal Surface Combatants category, there was an addition of four Diponegoro Class Frigates; in the Patrol and Coastal Combatants category, there was an addition of one Nala Class Corvette, one each of Cucut and Krait patrol boats, and ten Viper patrol boats. In the Amphibious category, the navy purchased two Makassar Principal Amphibious Vessels; in the Logistics and Support category, the navy added one each of Baruna Jaya Class Oceanographic Research Vessels and Tanjung Kambani Transports, and five Karang Pilang Transports. In the Aircraft category, the navy acquired one Maritime Patrol CN-235 MPA, seventeen Transport Light C-212-200 Aviocars, three Transport Light TB-9 Tampicos, and two Transport Light TB-10 Tobagos. In the Helicopter category, the navy added three Bo-105 units; in the Armored Infantry Fighting Vehicle category, there was an addition of thirty-seven BMP-3F and twelve BTR 80A units; in the Amphibious Assault Vehicle category, ten units LVTP-7A1 were purchased; and in the Artillery category, there was an addition of nine units of Multiple Rocket Launcher 122 mm RM-70.

The air force also acquired new combat aircraft (see next page). In the Fighter Ground Attack category, two Su-27 SK Flankers and three each of Su-27SKM and SuMK2 Flankers were purchased. In the Maritime Patrol category, there was an addition of three Boeing 737-200s and two CN-235-220 MPAs. The air force also purchased two CN-295 transport aircraft. 
Navy's Arms Acquistions, 2010-13

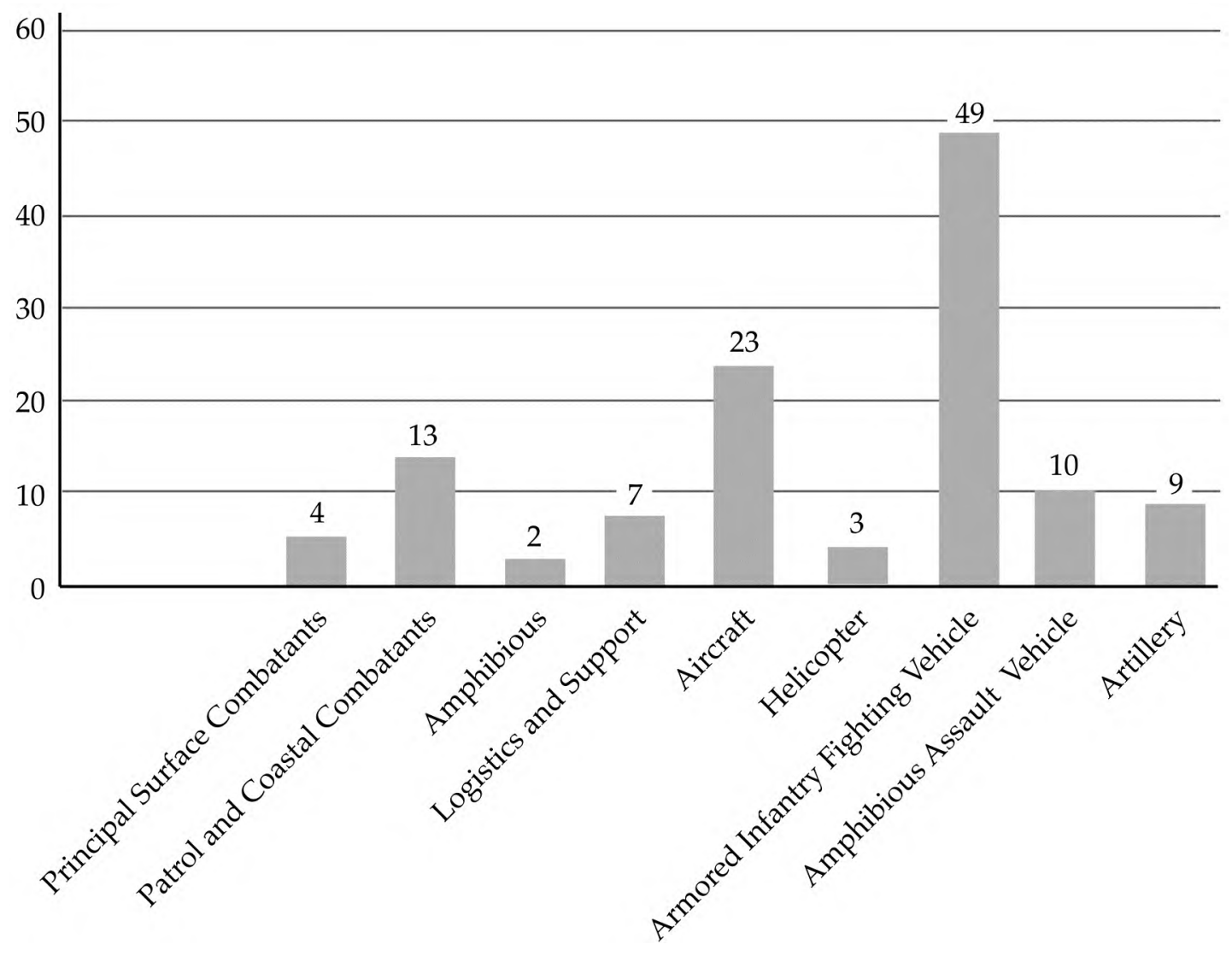

Air Force's Arms Acquistions, 2010-13

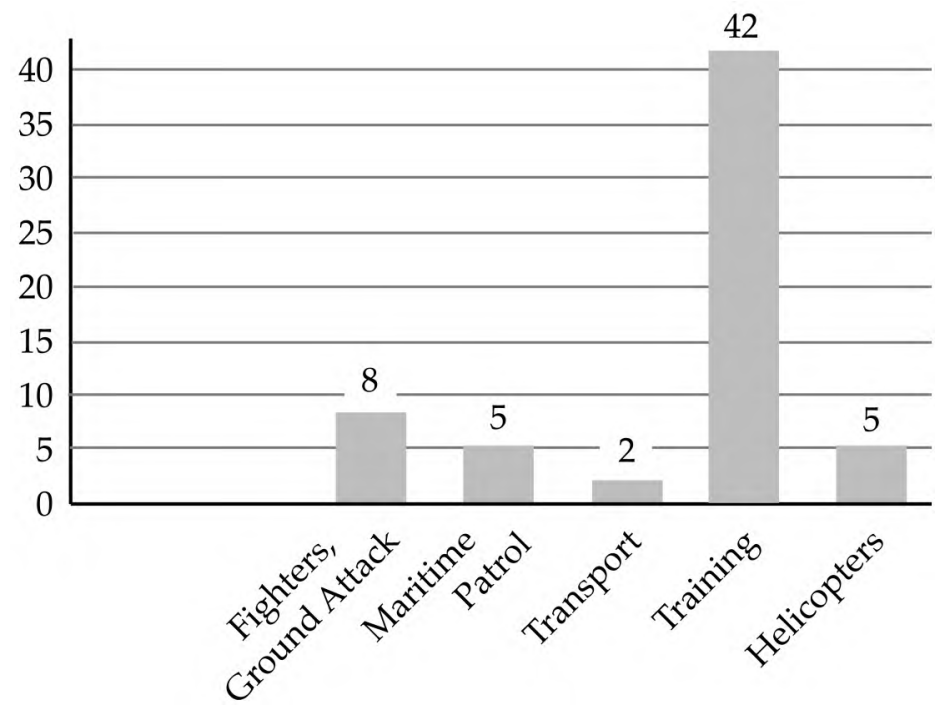


In the past four years, Indonesia intensively conducted military exercises and training sessions with foreign countries. Records show that more than one hundred joint military training activities were conducted during Suhartono's tenure. There were four joint military training activities in 2010 during September through December, eighteen military training activities in 2011, fifty-one joint military training activities in 2012, and, from January through August 2013, there were thirty-three more. ${ }^{31}$

\section{Joint Military Exercises and Training}

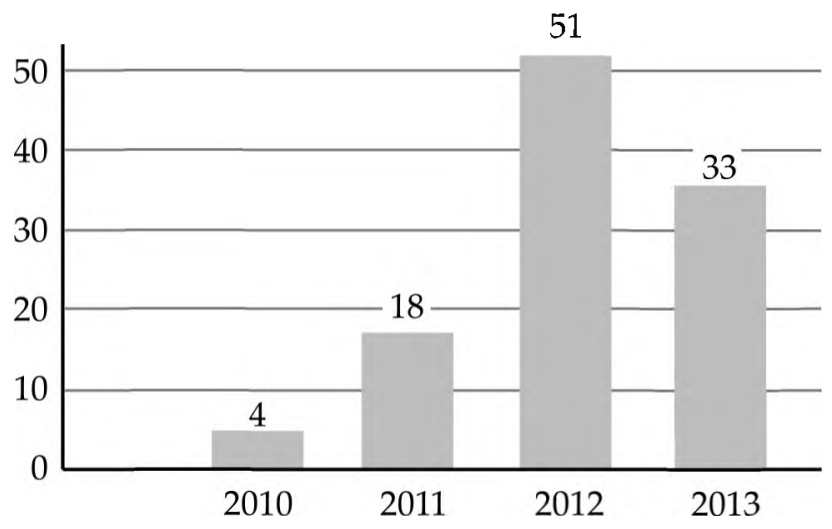

The majority of military exercises were conducted with the United States, fortyfour. Following the United States was Singapore, with nineteen collaborative activities. Indonesia also conducted a total of eight multilateral joint training exercises, which included the Kakadu Exercise in January 2013, an Air Maneuver Exercise in August 2012, the Southeast Asia Cooperation and Training (SEACAT) session, and the ASEAN disaster management exercise.

\section{Partner Countries}

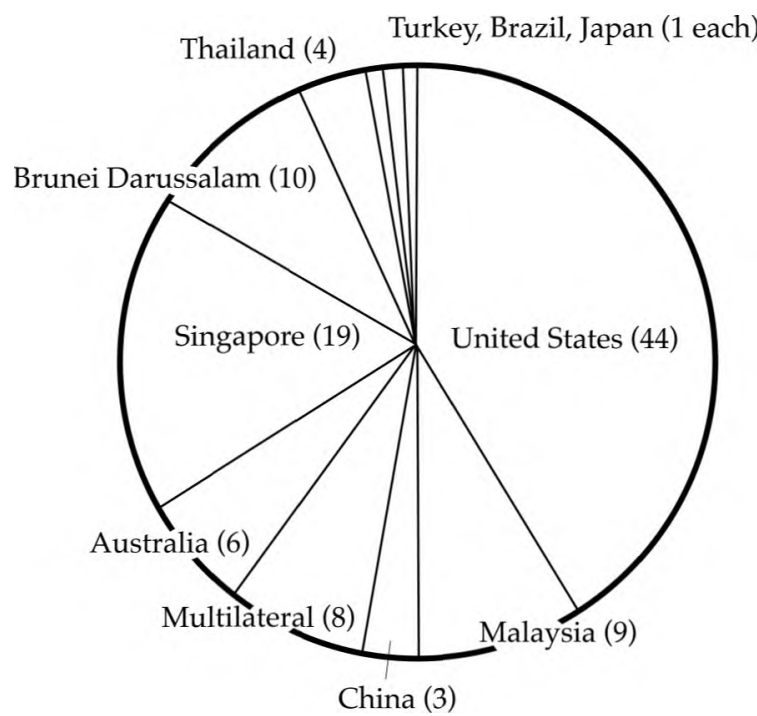

${ }^{31}$ The dataset highlighting Indonesia's foreign military training was derived from Derap TNI in the Harian Umum Pelita daily newspaper. 


\section{Concluding Remarks}

Over the past five years, TNI has undergone a generational transition in its officer corps. Under the military's new regime, led by high-ranking officers who were top graduates from the Military Academy, the relatively young officers of the 1980-83 classes find themselves in an environment that accommodates their commitment to military professionalism. In this regard, general conditions within TNI refer to the prioritizing of core military duties that relate to the defense of Indonesia as the key measurement for an officer to earn advancement. There are a number of reasons for this. First, given the small size of their classes (which averaged around a hundred officers per class), in the short term, the officers' ability and willingness to abide by professional norms may become a determining factor in rank promotions and military postings. With the current number of strategic posts within the military and defense establishments adequate for this cohort, young officers should feel secure about their career progression and rely on their professional competencies for key military positions. Postings outside the military establishment should then be less attractive relative to assignments requiring military officers to demonstrate their professional skills. Second, since TNI has established an ongoing plan to modernize the military's structure-including the establishment of a new airborne division under Kostradyoung officers may be eager to showcase their professional skills so as to attain prestigious military posts. Third, with growing terrorist and transnational threats, young officers may focus more on opting for missions that involve counter-terrorism, counter-maritime piracy, and border security tasks to demonstrate their military competencies and gain operational experience. They will also readily commit themselves to peacekeeping operations. Such assignments not only help them enhance their military credentials in pursuit of future promotion, but also provide them with extra financial benefits (around US $\$ 1,500$ per month for each officer).

Although personnel management may stabilize in the next few years, the road to professionalizing the armed forces remains an arduous climb. Fending off overtures from political parties will prove to be a significant challenge for TNI, particularly during a presidential election when the stakes are so high. If their seniors do not set a good example, the portents for the future are ominous, particularly considering the challenges facing the next generation of officers. Members of the Military Academy classes that graduated from 1984 to 1990 are competing with an average of 250 classmates for jobs and promotions. Without a comprehensive manpower planning strategy and merit-based promotion system, political processes will continue to affect institutional decisions for military postings. Instead of emphasizing professional competencies, the military will continue to be influenced by "parochial" factors such as political affiliation and primordial ties, and these will continue to act as key factors in determining promotion. In a highly competitive political environment, the biggest challenge for TNI leadership is to insulate personnel postings from political influences and maintain the sanctity of the merit-based rank promotion system. 
Roster of Key Positions and Commanding Officers

Indonesia National Defense Forces

(April 2008 to September 2013)

$* * * * * *$

\section{Cutoff Data: September 2013}

Key to roster:

Position: appointment and military rank (Commanding Officers)

- Officeholder

Date of birth

Academy class year (Akmil, military;

AAL, naval; AAU, air force)

Service background (specifically for the army)

Date of installation

Previous posting

Armed Forces HQ Headquarters

Position Commanding Officer (succession)

Commander-in-Chief of TNI

(General, Admiral, Air Chief Marshal)

- Gen. Djoko Santoso

b. 8 September 1952

Akmil 1975

Infantry

28 December 2007

Army Chief of Staff

- Admiral Agus Suhartono

b. 25 August 1955

AAL 1978

28 September 2010

Navy Chief of Staff

- Gen. Moeldoko

b. 8 July 1957

Akmil 1981

Infantry

30 August 2013

Army Chief of Staff
Chief of the General Staff

(Lieutenant General, Vice Admiral, Air Marshal)

- Vice Admiral Y. Didik Heru Purnomo b. 1954

AAL 1975

1 July 2008

Navy Deputy Chief of Staff

- Air Marshal Edy Harjoko

AAU 1975

23 October 2009

Commander, Sesko TNI

- Lt. Gen. Yohannes Suryo Prabowo

b. 15 June 1954

Akmil 1976

Combat Engineer (Zeni)

1 March 2011

Army Deputy Chief of Staff

- Air Marshal Daryatmo

b. 19 April 1955

AAU1978

1 August 2012

Head, BASARNAS

- Air Marshal Boy Syahril Qamar

b. 26 March 1956

AAU 1980

18 April 2013

Air Force Deputy Chief of Staff

Inspector General

(Lieutenant General, Vice Admiral, Air Marshal)

- Maj. Gen. Lilik AS. Sumaryo (promotion) Akmil 1975

Infantry

2 January 2008

Commander, Jakarta Garrison

- Maj. Gen. Muhammad Noer Muis

(promotion)

b. 22 August 1953

Akmil 1976

Infantry

10 May 2010

Commander, Kodam I/Bukit Barisan

- Air Marshal Sukirno

AAU 1977

6 June 2011

Air Force Deputy Chief of Staff 
114 The Editors

- Maj. Gen. Geerhan Lantara (promotion) b. 25 May 1956

Akmil 1978

Infantry

15 June 2012

Inspector General, Army HQ

Assistant for General Planning

(Major General, Rear Admiral, Air Vice Marshal)

- Air Vice Marshal Amirullah Amin AAU 1976

29 April 2008

Commander, Sesko AU

- Rear Admiral Among Margono

b. 13 April 1956

AAL 1978

23 May 2011

Assistant for Naval Planning

- Maj. Gen. Muktiyanto

Akmil 1980

Intendans

16 September 2013

Assistant for Army Planning

Assistant for Military Intelligence

(Major General, Rear Admiral, Air Vice Marshal)

- Maj. Gen. Anshory Tadjudin

Akmil 1975

Anti-air Artillery

26 September 2008

Expert Staff to Panglima TNI

- Maj. Gen. Rasyid Qurnuen Aquary

b. 13 January 1953

Akmil 1975

Infantry

30 November 2009

Commander, Kodam III/Siliwangi

- Maj. Gen. Tisna Komara

Akmil 1978

Infantry

6 August 2010

Assistant for Army Security Affairs
Assistant for Military Operations

(Major General, Rear Admiral, Air Vice Marshal)

- Maj. Gen. Supiadin Yusuf A.S. Akmil 1975

29 May 2008

Commander, Kodam Iskandar Muda

- Maj. Gen. Suhartono Suratman

b. 16 September 1952

Akmil 1974

Infantry

25 March 2010

Commander, Kodam VI/Tanjungpura

- Maj. Gen. Hambali Hanafiah

Akmil 1978

Infantry

6 October 2010

Commander, Kodam Iskandar Muda

- Maj. Gen. M. Ridwan

Akmil 1981

Infantry

18 August 2013

Commander, Kodam XII/Tanjungpura

Assistant for Military Territorial Affairs

(Major General)

- Maj. Gen. Suprapto

Akmil 1974

- Maj. Gen. Azmyn Yusri Nasution

b. 26 March 1954

Akmil 1977

Infantry

6 October 2010

Commander, Pusterad

- Maj. Gen. Langgeng Sulistyono

b. 1957

Akmil 1980

Combat engineer (Zeni)

25 July 2011

Commander, Kodam IV / Diponegoro

- Maj. Gen. Suwarno Widjonarko

Akmil 1980

Infantry

1 February 2012

Commander, Kodam II/Sriwijaya 
Assistant for Military Personnel

(Major General, Rear Admiral, Air Vice Marshal)

- Air Vice Marshal Agus Mudigdo b. 9 December 1951 AAU 1973

- Air Vice Marshal Sudjadijono AAU 1977 29 December 2009 Assistant for Air Force Personnel

- Air Vice Marshal Daryatmo

b. 19 April 1955

AAU 1978

6 October 2010

Commander, Kodikau

- Air Vice Marshal Bambang Wahyudi AAU 1978

25 July 2011

Expert Staff to Panglima TNI

Assistant for Military Logistics (Major General, Rear Admiral, Air Vice Marshal)

- Maj. Gen. Abdul Ghofur Akmil 1975

Logistics (Material)

26 September 2008

Assistant for Army Planning

- Maj. Gen. Hari Krisnomo

Akmil 1978

Field Artillery

10 May 2010

Commander, Kodam VII/ Wirabuana

- Maj. Gen. Joko Sriwidodo

Akmil 1978

Logistics (Material)

1 March 2013

Assistant for Army Logistics

Assistant for Military Electronic

Communications

(Major General, Rear Admiral, Air Vice

Marshal)

- Rear Admiral Muryono

AAL 197?

17 April 2007

Commander, Western Fleet
- Rear Admiral Sudjiwo

AAL 1975

10 May 2010

Assistant for Army Personnel

- Rear Admiral Slamet Yulistiyono

AAL 1980

22 August 2011

Commander, Kolinlamil

Head of Strategic Intelligence Body (BAIS)

(Major General, Rear Admiral,

Air Vice Marshal)

- Maj. Gen. Anshory Tadjudin

Akmil 1975

Anti-air Artillery

20 November 2009

Assistant for Military Intelligence

- Rear Admiral Soleman B. Ponto

b. 6 November 1955

AAL 1978

25 January 2011

Assistant for Navy Security

- Maj. Gen. Erwin Syafitri

b. 9 April 1959

Akmil 1982

Infantry

16 September 2013

Assistant for Army Security

Deputy Head of BAIS

(Major General, Rear Admiral, Air Vice Marshal)

- Air Commodore Teuku Djohan Basyar (promotion)

AAU 1977

18 December 2007

Deputy Commander, Koopsau I

- Brig. Gen. Erwin Syafitri (promotion)

b. 9 April 1959

Akmil 1982

Infantry

6 June 2011

Director A, BAIS

- Maj. Gen. Ibrahim Saleh

b. 21 December 1957

Akmil 1983

Infantry

1 February 2012

Assistant for Army Security 
Commander General, Military Academy [Akademi TNI]

(Major General, Rear Admiral, Air Vice Marshal)

- Maj. Gen. Nono Sampono

b. 1 March 1953

AAL 1976

Infantry

18 December 2007

Commander, Marines Corps

- Air Vice Marshal Sru Astjarjo Andreas b. 6 January 1956

AAU 1978

5 January 2011

Governor, Air Force Academy

- Air Vice Marshal Bambang Samoedro

b. 19 May 1959

AAU 1982

28 January 2013

Governor, Air Force Academy

Commander, Military Command and Staff College [Sesko TNI]

(Major General, Rear Admiral, Air Vice Marshal)

- Air Vice Marshal Edy Harjoko

AAU 1975

26 September 2008

Assistant for Air Force Operations

- Air Vice Marshal Eris Heryanto

AAU 1976

23 October 2009

Director General, Defense

Infrastructure (Ranahan), Ministry of

Defense

- Vice Admiral Moekhlas Sidik (backtrack)

b. 12 July 1953

AAL 1977

11 January 2010

Navy Deputy Chief of Staff

- Rear Admiral Mochamad Jurianto

AAL 1977

6 June 2011

Director General, Defense Material

(Kuathan), Ministry of Defense
- Air Vice Marshal Ida Bagus Putu Dunia b. 20 February 1957

AAU 1981

15 June 2012

Assistant for Air Force Personnel

- Air Vice Marshal Sunaryo

b. 14 July 1956

AAU 1982

December 2012

Director General, Defense Planning

(Renhan), Ministry of Defense

- Air Vice Marshal Ismono Wijayanto b. 1958

AAU 1983

18 April 2013

Assistant for Air Force Planning

Commander, Military Education and Training Command [Kodiklat TNI]

(Major General, Rear Admiral, Air Vice Marshal)

- Maj. Gen. Mochamad Sochib

Akmil 1975

Anti-air artillery

August 2010

Commander, Kodam II/Sriwijaya

- Maj. Gen. Djumadi

Akmil 1980

Infantry

27 September 2011

Expert Staff to Panglima TNI

- Maj. Gen. Chaidir Serunting Sakti

Akmil 1978

Cavalry

18 January 2013

Deputy Inspector General, Army HQ

Head, Military Logistics Body [Babek]

(Brigadier General, Commodore, Air Commodore)

- Brig. Gen. Johanes Budi Rahardjo Akmil 19??

Logistics

September 2009

- Brig. Gen. Suharno

Sepa Wamil 1983

Logistics

25 January 2011

Expert Staff to Panglima TNI 
- Col. Raharjo (promotion)

Sepa Wamil $19^{* *}$

Logistics

23 January 2013

Middle-ranking officer, Slog TNI HQ

Commander, Military Electronic

Communication Unit [Satkomlek]

(Brigadier General, Commodore, Air Commodore)

- Col. Abdul Rahim (promotion)

Akmil 1980

Electronic communication

29 December 2009

Deputy Commander, Satkomlek

- Col. Rusmanto (promotion)

Akmil 1983

Electronic communication

25 January 2011

Middle-ranking Officer, Skomlek TNI

- Col. Mulyanto (promotion)

Akmil 1981

Electronic communication

9 September 2013

Head, Data and Information Unit,

Ministry of Defense

Commander, Presidential Guards

[Paspampres]

(Major General)

- Brig. Gen. Marciano Norman (promotion)

b. 28 October 1954

Akmil 1978

Cavalry

26 September 2008

Director for Strategic Analysis,

Directorat General for Defense Strategy

(Strahan), Ministry of Defense

- Brig. Gen. Waris (promotion)

b. 12 December 1957

Akmil 1981

Infantry

10 May 2010

Chief of Staff, Kodam Jaya

- Brig. Gen. Agus Sutomo (promotion)

b. 14 August 1960

Akmil 1984

Infantry

1 March 2011

Deputy Commander, Kopassus
- Brig. Gen. Doni Munardo (promotion) b. 10 May 1963

Akmil 1985

Infantry

15 June 2012

Deputy Commander General,

Kopassus

Commander, Peace Keeping Center

(Brigadier General, Commodore and Air Commodore)

- Col. I Gede Sumertha K.Y. (promotion)

Akmil 1981

Combat Engineer (Zeni)

30 June 2008

Middle-rank officer, Directorate B, BAIS

- Col. Imam Edy Mulyono (promotion)

Akmil 1984

Infantry

22 August 2011

Middle-rank officer, Sopsad

- Col. A.M. Putranto (promotion)

Akmil 1987

Infantry

15 May 2013

Middle-rank officer, Srenad

Navy Headquarters

Navy Chief of Staff

(Admiral)

- Vice Admiral Tedjo Edhy Purdijatno (promotion)

b. 20 September 1952

AAL 1975

1 July 2008

Chief of General Staff

- Vice Admiral Agus Suhartono

(promotion)

b. 25 August 1955

AAL 1978

7 November 2009

Inspector General, Ministry of Defense

- Vice Admiral Soeparno (promotion)

b. 28 September 1955

AAL 1978

28 September 2010

Deputy Navy Chief of Staff 
- Vice Admiral Marsetio (promotion)

b. 3 December 1956

AAL 1981

17 December 2012

Deputy Navy Chief of Staff

Deputy Chief of Staff

(Vice Admiral)

- Rear Admiral Moekhlas Sidik (promotion)

b. 12 July 1953

AAL 1977

1 July 2008

Assistant for Naval Operations

- Rear Admiral Soeparno (promotion)

b. 28 September 1955

AAL 1978

11 January 2010

Assistant for Naval Operations

- Rear Admiral Marsetio (promotion)

b. 3 December 1956

AAL 1981

28 September 2010

Commander, Western Fleet

- Rear Admiral Hari Bowo (promotion)

b. 11 June 1956

AAL 1982

December 2012

Coordinator of Expert Staffs to Kasal

Commander, Western Fleet

(Rear Admiral)

- Commodore Soeparno (promotion)

b. 28 September 1955

AAL 1978

1 July 2008

Chief of Staff, Eastern Fleet

- Rear Admiral Marsetio

b. 3 December 1956

AAL 1981

23 October 2009

Commander, Kolinlamil

- Rear Admiral Hari Bowo

b. 11 June 1956

AAL 1982

28 September 2010

Governor, Naval Academy
- Rear Admiral Didit Herdiawan b. 13 September 1961

AAL 1984

22 August 2011

Commander, Kolinlamil

- Rear Admiral Sadiman

AAL 1981

21 June 2012

- Rear Admiral Arief Rudianto

AAL 1981

22 January 2013

Commander, Seskoal

Commander, Eastern Fleet

(Rear Admiral)

- Rear Admiral Lili Supramono

b. 24 October 1951

AAL 1977

17 January 2008

Commander, Kolinlamil

- Commodore Ignatius Dadiek Surarto (promotion)

b. 25 December 1953

AAL 1977

31 August 2009

Commander, Lantamal VI

- Rear Admiral Among Margono

b. 13 April 1956

AAL 1978

12 February 2010

Commander, Seskoal

- Rear Admiral Bambang Suwarto

b. 14 February 1956

AAL 1980

17 May 2010

Governor, Naval Academy

- Rear Admiral Ade Supandi

b. 26 May 1960

AAL 1983

25 July 2011

Governor, Naval Academy

- Rear Admiral Agung Pramono

AAL 1984

20 February 2012

Commander, Kolinlamil 
Commander, Military Sea Transport Command [Kolinlamil]

(Rear Admiral)

- Commodore Bambang Supeno (promotion)

b. 20 January 1952

AAL 197?

17 January 2008

Commander, Lantamal IX, Koarmatim

- Rear Admiral Slamet Yulistiyono

AAL 1980

23 October 2009

Expert Staff to Panglima TNI

- Commodore Didit Herdiawan (promotion)

b. 13 September 1961

AAL 1984

25 November 2010

Chief of Staff, Koarmabar

- Commodore Agung Pramono

(promotion)

AAL 1984

22 August 2011

Deputy Assistant for Naval Planning

- Commodore Admiral Sri Muhammad

Darojatim (promotion)

AAL 1982

20 February 2012

Deputy Commander, Seskoal

Commander, Marine Corps

(Major General)

- Brig. Gen. Djuhaidi Djahri (promotion)

AAL 1976

Marines

18 December 2007

Chief of Staff, Surabaya Garrison

- Brig. Gen. M. Alfan Baharudin

(promotion)

b. 30 May 1957

Marines

AAL 1981

2 September 2009

Deputy Commander, Presidential

Guards
- Brig. Gen. Ahmad Faridz Washington (promotion)

b. 27 December 1959

AAL 1983

Marines

1 August 2012

Chief of Staff, Marine Corps

Air Force Headquarters

Air Force

Air Force Chief of Staff

(Air Chief Marshal)

- Air Marshal Imam Sufaat (promotion)

b. 27 January 1955

AAU 1977

7 November 2009

Deputy Air Force Chief of Staff

- Air Marshal Ida Bagus Putu Dunia

(promotion)

b. 20 February 1957

AAU 1981

17 December 2012

Commander, Seskoau

Deputy Chief of Staff

(Air Marshal)

- Air Vice Marshal Wardjoko (promotion)

AAU 1975

16 July 2008

Assistant for Air Force Planning

- Air Vice Marshal Imam Sufaat

(promotion)

b. 27 January 1955

AAU 1977

23 October 2009

Commander, Koopsau I

- Air Vice Marshal Sukirno (promotion)

AAU 1977

11 January 2010

Assistant for Air Force Personnel

- Air Vice Marshal Dede Rusamsi

(promotion)

AAU 1981

6 June 2011

Commander, Koopsau I 
- Air Vice Marshal Boy Syahril Qamar (promotion)

b. 26 March 1956

AAU 1980

23 January 2013

Inspector General, Air Force HQ

- Air Vice Marshal Sunaryo (promotion)

b. 14 July 1956

AAU 1982

18 April 2013

Commander, Sesko TNI

Commander, Air Force Operation Command (Koopsau) I

(Air Vice Marshal)

- Air Vice Marshal Imam Sufaat

b. 27 January 1955

AAU 1977

16 July 2008

Governor, Air Force Academy

- Air Commodore Eddy Suyanto

(promotion)

AAU 1978

23 October 2009

Chief of Staff, Koopsau I

- Air Vice Marshal Dede Rusamsi

b. 19 December 1957

AAU 1981

2010

Expert Staff to Panglima TNI

- Air Commodore Sunaryo (promotion)

b. 14 July 1956

AAU 1982

6 June 2011

Deputy Governor, Air Force Academy

- Air Vice Marshal Bagus Puruhito

b. 3 October 1962

AAU 1984

20 February 2012

Commander, Kodikau

- Air Commodore Muhamad Syaugi (promotion)

b. 10 December 1960

AAU 1984

10 December 2012

Commander, Lanud Iswahjudi
Commander Koopsau II

(Air Vice Marshal)

- Air Vice Marshal Yushan Sayuti

AAU 197?

23 October 2008

- Air Vice Marshal Agus Munandar (promotion)

b. 30 January 1955

AAU 1980

February 2010

Commander, Lanud Adisutjipto

- Air Commodore Ismono Wijayanto (promotion)

b. 1958

AAU 1983

28 June 2011

Commander, Lanud Iswahjudi

- Air Commodore Agus Supriatna

(promotion)

AAU 1983

28 May 2012

Chief of Staff, Koopsau II

Commander, National Defense Command [Kohanudnas]

(Air Vice Marshal)

- Air Vice Marshal Dradjat Rahardjo

AAU 1976

26 September 2008

Commander, Kodikau

- Air Vice Marshal Eddy Suyanto

AAU 1978

28 September 2010

Commander, Koopsau I

- Air Vice Marshal Johnny Fritz

Pandapotan Sitompul

AAU 1980

July 2011

Expert Staff to Panglima TNI

- Air Vice Marshal F.Henry Bambang

Soelistyo

b. 11 February 1959

AAU 1982

29 May 2012

Deputy for Communication and

Information, Coordinating Ministry for

Politics, Law and Security Affairs 
- Air Vice Marshal Hadiyan Suminta

Atmadja

AAU 1983

28 January 2013

High-rank officer, TNI HQ

\section{Army Headquarters}

Army Chief of Staff

(General)

- Lt. Gen. Agustadi Sasongko Purnomo (promotion)

b. 6 August 1952

Akmil 1974

Infantry

28 December 2007

Secretary of Coordinating Ministry of

Political, Law and Security Affairs

- Lt. Gen. George Toisutta (promotion)

b. 1 June 1953

Akmil 1976

Infantry

7 November 2009

Commander, Kostrad

- Lt. Gen. Pramono Edhie Wibowo

(promotion)

b. 5 May 1955

Akmil 1980

Infantry

28 June 2011

Commander, Kostrad

- Lt. Gen. Moeldoko (promotion)

b. 8 July 1957

Akmil 1981

Infantry

20 May 2013

Army Deputy Chief of Staff

- Lt. Gen. Budiman (promotion) ${ }^{32}$

b. 25 September 1956

Akmil 1978

Combat engineer (Zeni)

30 August 2013

Secretary General, Ministry of Defense
Deputy Chief of Staff (Lieutenant General)

- Maj. Gen. Yohannes Suryo Prabowo (promotion)

b. 15 June 1954

Akmil 1976

Combat engineer (Zeni)

30 June 2008

Commander, Kodam Jaya

- Lt. Gen. Budiman

b. 25 September 1956

Akmil 1978

Combat engineer (Zeni)

1 March 2011

Commander, Kodiklatad

- Lt. Gen. Moeldoko

b. 8 July 1957

Akmil 1981

Infantry

23 January 2013

Deputy Governor, Lemhannas

- Lt. Gen. Muhamad Munir

b. 28 October 1958

Akmil 1983

Infantry

20 May 2013

Commander, Kostrad

Inspector General

(Major General)

- Maj. Gen. Georges R. Situmeang

Akmil 1974

Infantry

29 May 2008

Commander, Kodam IX/Udayana

- Maj. Gen. Djoko S. Utomo

Akmil 1975

Infantry

30 November 2009

Commander, Kodam VII/Wirabuana

- Maj. Gen. Soenarko

Akmil 1977

Infantry

October 2010

Commander, Pussenif Kodiklatad

${ }^{32}$ On July 21, 2014, Lt. Gen. Gatot Nurmantyo was officially installed as the new Army Chief of Staff. See: Keppres No 36/TNI/ 2014, dated July 21, 2014. 
- Maj. Gen. Rahmat Budiyanto

Akmil 1981

Field Artillery

4 May 2011

Commander, Kodam IX/Udayana

- Maj. Gen. Geerhan Lantara

b. 25 May 1956

Akmil 1978

Infantry

19 October 2011

Commander, Kodam XII/ Tanjungpura

- Maj. Gen. Adi Mulyono

b. 29 July 1955

Akmil 1981

Infantry

15 June 2012

Commander, Kodam Iskandar Muda

- Maj. Gen. Nugroho Widyotomo

Akmil 1984

Infantry

15 July 2013

Commander, Kodam II/Sriwijaya

Assistant for Army Security Affairs

(Major General)

- Maj. Gen. Hendardji Soepandji

b. 10 February 1952

Akmil 1974

Military police

18 December 2007

Commander, Puspomad

- Brig. Gen. Tisna Komara (promotion)

Akmil 1978

Infantry

1 March 2010

Expert Staff, BIN

- Brig. Gen. Leonard (promotion)

Akmil 1981

Infantry

28 September 2010

Head, Regional Office, BIN

- Brig. Gen. Ibrahim Saleh (promotion)

b. 21 December 1957

Akmil 1983

Infantry

4 May 2011

Chief of Staff, Kodam Jaya
- Maj. Gen. Eko Wiratmoko

Akmil 1982

Infantry

1 February 2012

Commander, Pusintelad

- Maj. Gen. Erwin Syafitri

b. 9 April 1959

Akmil 1982

Infantry

24 September 2012

Commander, Kodam

XVII/Cendrawasih

- Brig. Gen. Winston Simanjuntak

(promotion)

b. 12 June 1957

Akmil 1981

Infantry

16 September 2013

Chief of Staff, Kodam XVI/Patimura

Assistant for Army Operations

(Major General)

- Maj. Gen. Hotma Marbun

Akmil 1977

Infantry

26 September 2008

Commander, Seskoad

- Maj. Gen. Haryadi Soetanto

Akmil 1975

Infantry

30 November 2009

Commander, Kodam IV/ Diponegoro

- Brig. Gen. Hardiono Saroso (promotion)

Akmil 1981

Infantry

2 May 2011

Chief of Staff, Kodam IV/Diponegoro

- Maj. Gen. Dedi Kusnadi Thamim

b. 31 August 1958

Akmil 1982

Infantry

6 July 2012

Commander, Pussenif

- Maj. Gen. Mulyono

Akmil 1983

Infantry

18 August 2013

Deputy Commander, Kodiklatad 
Assistant for Army Personnel

(Major General)

- Maj. Gen. Arri Sujono

Akmil 1974

Infantry

29 May 2008

Expert Staff to Panglima TNI

- Brig. Gen. Ali Yusuf Susanto (promotion) Akmil 1976

Combat Engineer (Zeni)

10 May 2010

Director for Material, Directorate General Defense Material (Kuathan), Ministry of Defense

- Brig. Gen. Sunindyo (promotion)

b. 4 April 1959

Akmil 1983

Infantry

5 May 2012

Chief of Staff, Kodam IV/Diponegoro

- Maj. Gen. Istu H. Subagio

Akmil 1983

Infantry

5 April 2013

Governor, Akmil

Assistant for Army Logistics

(Major General)

- Brig. Gen. Wibowo (promotion)

Akmil 1975

Infantry

30 November 2009

Chief of Staff, Kodam VII/Wirabuana

- Brig. Gen. Sonny Widjaya (promotion)

Akmil 1982

Infantry

2 May 2011

Director for Doctrine, Kodiklatad

- Brig. Gen. Joko Sriwidodo (promotion)

Akmil 1978

Logistics (Material)

20 February 2012

Director, Palad

- Brig. Gen. P. Prasetyanto (promotion)

Akmil 1980

1 March 2013

Director, Palad
Assistant for Army Planning

(Major General)

- Maj. Gen. Karsidi

b. 17 March 1952

Akmil 1974

Infantry

26 September 2008

Lecturer, Lemhannas

- Brig. Gen. Mulhim Asyrof (promotion)

b. 23 July 1954

Akmil 1976

Combat Engineer (Zeni)

25 March 2010

Director for Construction, Directorate

General for Defense Infrastructure

(Ranahan), Ministry of Defense

- Brig. Gen. Subekti (promotion)

b. 5 March 1956

Akmil 1980

Field Artillery

25 July 2011

Chief of Staff, Kodam VII/Wirabuana

- Brig. Gen. Dicky Wainal Usman

(promotion)

b. 28 April 1957

Akmil 1980

Combat Engineer (Zeni)

20 February 2012

Director, Ziad

- Maj. Gen. Muktiyanto

Akmil 1980

Intendans

24 September 2012

Coordinator of Expert Staffs to Kasad

- Brig. Gen. Wiryantoro N.K. (promotion) Akmil 198?

16 September 2013

Deputy Assistant for Army Planning

Assistant for Army Territorial Affairs

(Major General)

- Maj. Gen. Karsidi

Akmil 1974

Infantry

29 May 2008

Expert Staff to Panglima TNI 
- Brig. Gen. Jul Effendi Sjarief (promotion) Akmil 1976

Infantry

1 March 2010

Deputy Assistant for Army Territorial Affairs

- Brig. Gen. Thomas Edy Widagdo (promotion)

Akmil 1978

Field Artillery

4 May 2011

Chief of Staff, Kodam XVI/Patimura

- Maj. Gen. Bachtiar

Akmil 1984

Infantry

14 November 2012

Expert Staff to Kasad

- Maj. Gen. Meris Wiryadi

Akmil 1983

Infantry

24 April 2013

Expert Staff to Panglima TNI

Governor, Military Academy (Akmil)

(Major General)

- Brig. Gen. Gatot Nurmantyo (promotion)

b. 13 March 1960

Akmil 1982

Infantry

29 December 2009

Director for Training, Kodiklatad

- Brig. Gen. Suharsono (promotion)

Akmil 1977

Cavalry

8 September 2010

Chief of Staff, Kodam II/Sriwijaya

- Brig. Gen. Bachtiar (promotion)

Akmil 1984

Infantry

25 January 2011

Commander, Secapaad

- Brig. Gen. Istu H. Subagio (promotion)

Akmil 1983

Infantry

5 June 2012

Deputy Assistant for Military

Personnel
- Brig. Gen. Sumardi (promotion) Akmil 1981

Infantry

5 April 2013

Chief of Staff, Jakarta Garrison

Commander, Army Command and Staff College [Seskoad]

(Major General)

- Maj. Gen. Bambang Suranto

b. 6 October 1952

Akmil 1974

Infantry

26 September 2008

Commander, Kodam V/Brawijaya

- Maj. Gen. Markus Kusnowo

Akmil 1975

Infantry

1 March 2010

Chief of Staff, Kostrad

- Brig. Gen. Nanang Djuana Priadi

(promotion)

Akmil 1977

Infantry

6 October 2010

Deputy Commander, Seskoad

- Maj. Gen. Burhanuddin Siagian

b. 10 November 1955

Akmil 1981

Cavalry

27 September 2011

Commander, Pussenkav

- Maj. Gen. Arief Rachman

Akmil 1980

Infantry

20 May 2013

Coordinator of Expert Staff, Kasad

Commander, Army's Territorial Center

[Pusterad]

(Major General)

- Maj. Gen. Azmyn Yusri Nasution

b. 26 March 1954

Akmil 1977

Infantry

17 November 2009

Commander, Kodam

XVII/Cendrawasih 
- Maj. Gen. Markus Kusnowo Akmil 1975

Infantry

6 October 2010

Commander, Seskoad

- Maj. Gen. Wibowo

Akmil 1975

Infantry

2 May 2011

Assistant for Army Logistics

- Brig. Gen. Indra Hidayat R. (promotion) Akmil 198?

Infantry

21 November 2011

Chief of Staff, Kodam

XVII/Cendrawasih

- Maj. Gen. Zahari Siregar

b. 9 March 1957

Akmil 1980

Infantry

18 August 2013

Commander, Kodam Iskandar Muda

Commander, Army's Military Police Center [Puspomad]

(Major General)

- Brig. Gen. Sutarno Soepodo (promotion)

b. 4 October 1953

Akmil 1976

Military Police

12 February 2010

Expert Staff to Panglima TNI

- Brig. Gen. Iran Syaefudin (promotion)

Akmil 1980

Military Police

27 September 2011

Deputy Commander, Puspomad

- Brig. Gen. Unggul Kawistoro Yudoyono (promotion)

Akmil 1981

Military Police

9 September 2013

Deputy Commander, Puspomad
Commander, Army Aviation Center (Pusnerbad)

(Brigadier General)

- Col. Poltak MP. Sidabutar (promotion)

Akmil 1975

Army Aviation

17 January 2008

Commander, Education Center,

Pusnerbad

- Col. Moch. Wahyu Riyanto (promotion) Akmil 1977

Army Aviation

2010

- Col. Gen. Moch. Afifuddin (promotion)

Akmil 1985

Army Aviation

1 August 2012

Director for Proficiency Development, Pusnerbad

Commander, Army Intelligence Center [Pusintelad]

(Brigadier General)

- Col. Ngakan Gede Sugiartha (promotion) Akmil 1981

Infantry

February 2008

- Col. Ibrahim Saleh (promotion)

b. 21 December 1957

Akmil 1983

Infantry

29 December 2009

Middle-rank officer, Army HQ

- Col. Eko Wiratmoko (promotion)

Akmil 1982

Infantry

28 September 2010

Commander, Army HQ Detachment

- Col. Teddy Lhaksmana W.K. (promotion) Akmil 1983

Infantry

1 February 2012

Commander, Army HQ Detachment 
Commander, Army Education and Training Command [Kodiklatad]

(Lieutenant General)

- Maj. Gen. Syaiful Rizal (promotion) Akmil 1975

Infantry

26 September 2008

Assistant for Army Operations

- Maj. Gen. Budiman (promotion)

b. 25 September 1956

Akmil 1978

Combat Engineer (Zeni)

10 May 2010

Commander, Kodam IV/Diponegoro

- Maj. Gen. Marciano Norman (promotion)

b. 28 October 1954

Akmil 1978

Cavalry

1 March 2011

Commander, Kodam Jaya

- Maj. Gen. Gatot Nurmantyo (promotion)

b. 13 March 1960

Akmil 1982

Infantry

17 October 2011

Commander, Kodam V/Brawijaya

- Maj. Gen. Lodewijk Freidrich Paulus (promotion)

b. 27 July 1957

Akmil 1981

Infantry

20 May 2013

Commander, Kodam I/Bukit Barisan

Commander, Army Infantry Center

[Pussenif]

(Major General)

- Maj. Gen. Soenarko

Akmil 1977

Infantry

23 October 2009

Commander, Kodam Iskandar Muda

- Brig. Gen. Siswondo (promotion)

Akmil 1977

Infantry

October 2010

Deputy Commander, Pussenif
- Brig. Gen. Wisnu Bawa Tenaya

(promotion)

b. 24 April 1958

Akmil 1981

Infantry

6 June 2011

Chief of Staff, Kodam VI/Mulawarman

- Brig. Gen. Erwin Hudawi Lubis

(promotion)

b. 7 August 1956

Akmil 1980

Infantry

6 September 2011

Deputy assistant to Coordinator for

Defense Intelligence, Coordinating

Ministry for Politics, Law and Security

Affairs

- Brig. Gen. Nugroho Widyotomo

(promotion)

Akmil 1984

Infantry

19 October 2011

Expert Staff to Panglima TNI

- Brig. Gen. Dedi Kusnadi Thamim

(promotion)

b. 31 August 1958

Akmil 1982

Infantry

1 February 2012

Chief of Staff, Kodam IV/Diponegoro

- Brig. Gen. Mochamad Nasir (promotion)

Akmil 1980

6 July 2012

Chief of Staff, Kodam II/Sriwijaya

- Brig. Gen. I Made Agra Sudiantara

(promotion)

b. 26 March 1962

Akmil 1985

Infantry

1 July 2013

Expert Staff to Kasad 
Commander, Army Cavalry Center [Pussenkav]

(Brigadier General)

- Col. Burhanuddin Siagian (promotion) b. 10 November 1955

Akmil 1981

Cavalry

2010

Inspector for Intelligence Affairs, Irjenad

- Col. Purwadi Mukson (promotion)

b. 21 February 1959

Akmil 1982

Cavalry

27 September 2011

Deputy Commander, Pussenkav

- Col. Mulyanto (promotion)

Akmil 1983

Cavalry

1 July 2013

Deputy Commander, Pussenkav

Commander, Army Field Artillery Center [Pussenarmed]

(Brigadier General)

- Col. A.A. Gde Suardhana (promotion)

Akmil 1978

Field Artillery

25 March 2010

Expert Staff to Pangdam

VII/Wirabuana

- Col. Ediwan Prabowo (promotion)

b. 4 October 1961

Akmil 1984

Field Artillery

February 2011

- Col. Ariyadi Padmanegara (promotion)

Akmil 1983

Field Artillery

22 August 2011

Middle-ranking officer, Srenad

- Col. Sohadji (promotion)

Akmil 1984

Field Artillery

16 September 2013

Middle-ranking officer, Srenad
Commander, Army Anti-Air Artillery Center [Pussenarhanud]

(Brigadier General)

- Col. Sudharmanto (promotion)

Akmil 1978

Anti-air Artillery

$<2012$

- Col. Hadi Prasojo (promotion)

Akmil 1983

Anti-air Artillery

1 August 2012

Middle-rank officer, Army HQ

Detachment

Commander, Army Strategic Command

[Kostrad]

(Lieutenant General)

- Brig. Gen. Burhanudin Amin (promotion)

b. 5 November 1952

Akmil 1976

Infantry

11 January 2010

Commander, Kodam I/ Bukit Barisan

- Maj. Gen. Pramono Edhie Wibowo

(promotion)

b. 5 May 1955

Akmil 1980

Infantry

28 September 2010

Commander, Kodam III/Siliwangi

- Maj. Gen. Azmyn Yusri Nasution

(promotion)

b. 26 March 1954

Akmil 1977

Infantry

25 July 2011

Assistant for Military Territorial Affairs

- Maj. Gen. Muhamad Munir (promotion)

b. 28 October 1958

Akmil 1983

Infantry

20 February 2012

Commander, Kodam III/Siliwangi

- Lt. Gen. Gatot Nurmantyo

b. 13 March 1960

Akmil 1982

Infantry

20 May 2013

Commander, Kodiklatad 
Chief of Staff, Kostrad

(Major General)

- Maj. Gen. Hendra Rizal

Akmil 1976

Infantry

9 June 2010

Lecturer, Lemhannas

- Maj. Gen. Zahari Siregar

b. 9 March 1957

Akmil 1980

Infantry

17 October 2011

Deputy Inspector General, TNI HQ

- Maj. Gen. Harry Purdianto

Akmil 1981

Infantry

6 July 2012

Commander, Infantry Division-1, Kostrad

- Maj. Gen. Indra Hidayat R.

Akmil 198?

Infantry

18 August 2013

Commander, Pusterad

Commander, Infantry Division-1, Kostrad

- Brig. Gen. Hatta Syarifudin (promotion)

Akmil 1976

Infantry

November 2007

Deputy Assistant for Army Territorial Affairs

- Brig. Gen. Moeldoko (promotion)

b. 8 July 1957

Akmil 1981

Infantry

11 January 2010

Chief of Staff, Kodam Jaya

- Brig. Gen. Adi Mulyono (promotion)

b.29 July 1955

Akmil 1981

Infantry

10 May 2010

Inspector for General Affairs, Itjenad
- Brig. Gen. Muhamad Nizam (promotion) Akmil 1981

Infantry

6 October 2010

Chief of Staff, Kodam IV/Diponegoro

- Brig. Gen. Harry Purdianto (promotion) Akmil 1981

Infantry

6 September 2011

Chief of Staff, Kodam II/Sriwijaya

- Brig. Gen. Daniel Ambat (promotion)

Akmil 1983

Infantry

6 July 2012

Chief of Staff, Kodam

XVII/Cendrawasih

Chief of Staff, Infantry Division-1, Kostrad

(Brigadier General)

- Brig. Gen. Nugroho Widyotomo

Akmil 1984

Infantry

2010

Deputy Commander, Kopassus

- Col. Agus Sutomo (promotion)

b. 14 August 1960

Akmil 1984

Infantry

2010

Commander, Korem 061/Surya

Kancana, Kodam III/Siliwangi

- Col. Amrid Salas Kembaren (promotion)

Akmil 1981

Infantry

2 May 2011

Inspector, Kodam Jaya

- Col. Asrobudi (promotion)

Akmil 1985

Infantry

1 August 2012

Middle-rank officer, Army HQ

Detachment

- Col. Agus Rohman (promotion)

Akmil 1988

Infantry

24 April 2013

Commander, Korem 061/Surya

Kancana, Kodam III/Siliwangi 
Commander, Infantry Division-2, Kostrad (Major General)

- Brig. Gen. Zahari Siregar (promotion)

b. 9 March 1957

Akmil 1980

Infantry

30 June 2008

Head, Peacekeeping Center

- Brig. Gen. Geerhan Lantara (promotion)

b. 25 May 1956

Akmil 1978

Infantry

29 December 2009

Inspector for General Affairs, Itjenad

- Brig. Gen. Muhamad Munir (promotion)

b. 28 October 1958

Akmil 1983

Infantry

28 September 2010

Chief of Staff, Kodam Jaya

- Brig. Gen. M. Ridwan (promotion)

Akmil 1981

Infantry

25 July 2011

Commander, Secapaad

- Brig. Gen. Setyo Sularso (promotion)

Akmil 1982

Infantry

1 August 2012

Chief of Staff, Kodam V/Brawijaya

- Brig. Gen. Agus Kriswanto (promotion)

Akmil 1984

Infantry

15 July 2013

Chief of Staff, Kodam IV/Diponegoro

Chief of Staff, Infantry Division-2, Kostrad (Brigadier General)

- Col. Harry Purdianto (promotion)

Akmil 1981

Infantry

23 October 2009

Inspector for Personnel Affairs, Itjenad

- Brig. Gen. Syahiding Anwar

Akmil 1983

Infantry

8 September 2010

High-rank officer, Army HQ
- Brig. Gen. Anas Alwi

Akmil 1981

Infantry

6 July 2012

Deputy Assistant for Army Security Affairs

- Brig. Gen. Tatang Sulaiman

Akmil 1986

Infantry

24 April 2013

Deputy Commander, Pussenif

Commander General, Army Special Forces Command [Kopassus]

(Major General)

- Brig. Gen. Pramono Edhie Wibowo (promotion)

b. 5 May 1955

Akmil 1980

Infantry

28 Mei 2008

Chief of Staff, Kodam IV/Diponegoro

- Brig. Gen. Lodewijk Freidrich Paulus (promotion)

b. 27 July 1957

Akmil 1981

Infantry

23 October 2009

Director for Training, Kodiklatad

- Maj. Gen. Wisnu Bawa Tenaya

b. 24 April 1958

Akmil 1981

Infantry

6 September 2011

Commander, Pussenif

- Maj. Gen. Agus Sutomo

b. 14 August 1960

Akmil 1984

Infantry

15 June 2012

Commander, Presidential Guards

Deputy Commander, Kopassus

(Brigadier General)

- Col. Nugroho Widyotomo (promotion)

Akmil 1984

Infantry

25 March 2010

Commander, Korem 043/Black Eagle,

Kodam II/Sriwijaya 
- Brig. Gen. Agus Sutomo

b. 14 August 1960

Akmil 1984

Infantry

2010

Chief of Staff, Infantry Division-1,

Kostrad

- Col. Doni Munardo (promotion)

b. 10 May 1963

Akmil 1985

Infantry

1 March 2011

Commander, Korem 061/Surya

Kancana, Kodam Siliwangi

- Col. Jaswandi (promotion)

Akmil 1985

Infantry

15 June 2012

Middle-rank officer, Army HQ

Detachment

- Col. Muhammad Herindra (promotion)

Akmil 1987

Infantry

10 June 2013

Commander, Korem 101/Antasari,

Kodam VI/Mulawarman

Commander, Military Region (Kodam) I/ Bukit Barisan

(Major General)

- Maj. Gen. Burhanudin Amin

b. 5 November 1952

Akmil 1976

Infantry

3 November 2008

Expert Staff, Lemhannas

- Maj. Gen. Muhammad Noer Muis

b. 22 August 1953

Akmil 1976

Infantry

11 January 2010

Commander, Kodam XVI/Patimura

- Brig. Gen. Leonardus JP. Siegers

(promotion)

b. 29 August 1956

Akmil 1978

Anti-Air Artillery

10 May 2010

Chief of Staff, Kodam V/Brawijaya
- Maj. Gen. Lodewijk Freidrich Paulus

b. 27 July 1957

Akmil 1981

Infantry

6 September 2011

Commander General, Kopassus

- Maj. Gen. Burhanuddin Siagian

b. 10 November 1955

Akmil 1981

Cavalry

20 May 2013

Commander, Seskoad

Chief of Staff, Kodam I/Bukit Barisan

(Brigadier General)

- Brig. Gen. Asman Yusri Yusuf

Akmil 1976

Infantry

February 2008

Expert Staff to Kasad

- Brig. Gen. Murdjito

b. 1 March 1955

Akmil 1980

Infantry

24 September 2010

Deputy Assistant for Army Personnel

- Brig. Gen. I Gede Sumertha K.Y.

Akmil 1981

Combat Engineer (Zeni)

September 2011

- Brig. Gen. Andogo Wiradi

Akmil 1981

Infantry

18 August 2013

Assistant Deputy to Coordinator for

Defense Intelligence, Coordinating

Ministry for Politics, Law and Security

Affairs

Commander, Kodam II/Sriwijaya

(Major General)

- Maj. Gen. Mochamad Sochib

Akmil 1975

Anti-air artillery

17 January 2008

Commander, Seskoad 
- Brig. Gen. Agus Gunaedi Pribadi (promotion)

b. 15 August 1953

Akmil 1977

Infantry

August 2010

Commander, Secapaad

- Maj. Gen. Suwarno Widjonarko

Akmil 1980

Infantry

2 May 2011

Lecturer, Lemhannas

- Maj. Gen. Nugroho Widyotomo

Akmil 1984

Infantry

1 February 2012

Commander, Pussenif

- Maj. Gen. Bambang Budi Waluyo

b. 19 November 1956

Akmil 1981

Infantry

15 July 2013

Lecturer, Lemhannas

Chief of Staff, Kodam II/Sriwijaya

(Brigadier General)

- Brig. Gen. Junianto Haroen

b. 23 June 1954

Akmil 1976

Infantry

25 October 2007

Director for Doctrine, Kodiklatad

- Brig. Gen. Suharsono

Akmil 1977

Cavalry

25 March 2010

Commander, Pussenkav

- Brig. Gen. Harry Purdianto

Akmil 1981

Infantry

8 September 2010

Chief of Staff, Infantry Division-2,

Kostrad

- Brig. Gen. Mochamad Nasir

Akmil 1980

6 September 2011

Head, Disjasad
- Brig. Gen. Syahiding Anwar

Akmil 1983

Infantry

6 July 2012

Chief of Staff, Infantry Division-2,

Kostrad

- Brig. Gen. Toto S. Murasad

b. 11 April 1957

Akmil 1983

Infantry

30 August 2013

Deputy Assistant, Election Affairs, Coordinating Ministry for Politics, Law and Security Affairs

Commander, Kodam III/Siliwangi

(Major General)

- Maj. Gen. Pramono Edhie Wibowo

b. 5 May 1955

Akmil 1980

Infantry

23 October 2009

Commander General, Kopassus

- Maj. Gen. Moeldoko

b. 8 July 1957

Akmil 1981

Infantry

28 September 2010

Commander, Kodam XII/Tanjungpura

- Maj. Gen. Muhamad Munir

b. 28 October 1958

Akmil 1983

Infantry

25 July 2011

Commander, Infantry Division-2,

Kostrad

- Maj. Gen. Sonny Widjaya

Akmil 1982

Infantry

20 February 2012

Assistant for Army Logistics

- Maj. Gen. Dedi Kusnadi Thamim

b. 31 August 1958

Akmil 1982

Infantry

18 August 2013

Assistant for Army Operations 
Chief of Staff, Kodam III/Siliwangi

(Brigadier General)

- Brig. Gen. Rahmat Budiyanto

Akmil 1981

Field Artillery

29 May 2008

Expert Staff to Panglima TNI

- Brig. Gen. Hadi Lukmono

Akmil 1977

Field Artillery

25 March 2010

Head, Dispsiad

- Brig. Gen. Meris Wiryadi

Akmil 1983

Infantry

4 May 2011

Expert Staff to Panglima TNI

- Brig. Gen. Sudirman Kadir

Akmil 1981

Infantry

23 December 2011

Assistant Deputy for Army Operations

- Brig. Gen. Suyatno

Akmil 1981

Infantry

24 April 2013

Expert Staff to Kasad

Commander, Kodam IV/Diponegoro

(Major General)

- Maj. Gen. Haryadi Soetanto

Akmil 1975

Infantry

30 June 2008

Commander, Kodam

XVII/Cendrawasih

- Maj. Gen. Budiman

b. 25 September 1956

Akmil 1978

Combat Engineer (Zeni)

30 November 2009

Presidential Military Secretary
- Brig. Gen. Langgeng Sulistyono (promotion)

b. 1957

Akmil 1980

Combat Engineer (Zeni)

10 May 2010

Chief of Staff, Kodam IV/Diponegoro

- Maj. Gen. Mulhim Asyrof

b. 23 July 1954

Akmil 1976

Combat Engineer (Zeni)

25 July 2011

Assistant for Army Planning

- Maj. Gen. Hardiono Saroso

Akmil 1981

Infantry

6 July 2012

Assistant for Army Operations

- Maj. Gen. Sunindyo

b. 4 April 1959

Akmil 1983

Infantry

5 April 2013

Assistant for Army Personnel

Chief of Staff, Kodam IV/Diponegoro

(Brigadier General)

- Brig. Gen. Muhamad Nizam

Akmil 1981

Infantry

10 May 2010

Head, Disjasad

- Brig. Gen. Hardiono Saroso

Akmil 1981

Infantry

6 October 2010

Deputy Governor, Akmil

- Brig. Gen. Nugroho Widyotomo

Akmil 1984

Infantry

2 May 2011

Chief of Staff, Infantry Division-1,

Kostrad

- Col. Dedi Kusnadi Thamim (promotion)

b. 31 August 1958

Akmil 1982

Infantry

October 2011

Inspector, Kodam VII/Wirabuana 
- Brig. Gen. Sunindyo

b. 4 April 1959

Akmil 1983

Infantry

1 February 2012

Secretary, Kodiklatad

- Brig. Gen. Agus Kriswanto

Akmil 1984

Infantry

5 May 2012

Director for Education, Kodiklatad

- Brig. Gen. Ibnu Darmawan

Akmil 1983

Infantry

15 July 2013

Deputy Assistant to Coordinator of

Defense Intelligence, Coordinating

Ministry for Politics, Law and Security

Affairs

Commander, Kodam V/Brawijaya

(Major General)

- Maj. Gen. Suwarno

b. 3 May 1955

Akmil 1977

Cavalry

26 September 2008

Commander, Presidential Guards

- Maj. Gen. Gatot Nurmantyo

b. 13 March 1960

Akmil 1982

Infantry

8 September 2010

Governor, Military Academy

- Maj. Gen. Murdjito

b. 1 March 1955

Akmil 1980

Infantry

17 October 2011

Expert Staff to Panglima TNI

- Maj. Gen. Ediwan Prabowo

b. 4 October 1961

Akmil 1984

Field Artillery

28 January 2013

Head, Baranahan, Ministry of Defense
Chief of Staff, Kodam V/Brawijaya

(Brigadier General)

- Brig. Gen. Leonardus JP. Siegers

b. 29 August 1956

Akmil 1978

Anti-air Artillery

25 March 2010

Commander, Pusarhanud

- Brig. Gen. Avianto Saptono

Akmil 1981

Combat Engineer (Zeni)

10 May 2010

Chief of Staff, Jakarta Garrison

- Brig. Gen. Setyo Sularso

Akmil 1982

Infantry

6 October 2010

Deputy, Puspen TNI

- Brig. Gen. Amrid Salas Kembaren

Akmil 1981

Infantry

1 August 2012

Chief of Staff, Infantry Division-1,

Kostrad

- Brig. Gen. Asma'i

b. 1956

Akmil 1982

Infantry

18 August 2013

Director for Evaluation and

Development, Kodiklatad

Commander, Kodam VI/Mulawarman (Major General)

- Maj. Gen. Suhartono Suratman

b. 16 September 1952

Akmil 1974

Infantry

January 2008

Assistant for Army Security Affairs

- Brig. Gen. Tan Aspan (promotion)

Akmil 1976

Infantry

25 March 2010

Chief of Staff, Kodam

XVII/Tanjungpura 
- Maj. Gen. Subekti

b. 5 March 1956

Akmil 1980

Field Artillery

20 February 2012

Assistant for Army Planning

- Maj. Gen. Dicky Wainal Usman

b. 28 April 1957

Akmil 1980

Combat Engineer (Zeni)

24 September 2012

Assistant for Army Planning

Chief of Staff, Kodam VI/Mulawarman

(Brigadier General)

- Brig. Gen. Tan Aspan

Akmil 1976

Infantry

5 May 2009

Deputy Assistant for Defense Intelligence, Coordinating Ministry for

Politics, Law and Security Affairs

- Brig. Gen. Wisnu Bawa Tenaya

b. 24 April 1958

Akmil 1981

Infantry

25 March 2010

Deputy Commander, Kopassus

- Brig. Gen. O. Sudjatmiko

Akmil 1978

Cavalry

6 June 2011

Secretary, Kodiklatad

- Brig. Gen. Wiyarto

Akmil 1985

Infantry

5 May 2012

Deputy Assistant for Army Personnel

- Brig. Gen. Abdul Kadir Sultan

Akmil 1981

Infantry

18 August 2013

Deputy Assistant for Army Territorial Affairs
Commander, Kodam VII/ Wirabuana

(Major General)

- Maj. Gen. Hari Krisnomo

Akmil 1978

Field Artillery

30 November 2009

Assistant for Army Logistics

- Maj. Gen. Amril Amir

Akmil 1978

Infantry

10 May 2010

Chief of Staff, Kodam VII/Wirabuana

- Maj. Gen. Muhamad Nizam

Akmil 1981

Infantry

6 September 2011

Commander, Infantry Division-1,

Kostrad

- Maj. Gen. Bachtiar

Akmil 1984

Infantry

10 June 2013

Assistant for Army Territorial Affairs

Chief of Staff, Kodam VII/Wirabuana

(Brigadier General)

- Brig. Gen. Amril Amir

Akmil 1978

Infantry

30 November 2009

Head, Disjarahad

- Brig. Gen. Subekti

b. 5 March 1956

Akmil 1980

Field Artillery

10 May 2010

Director for Strategic Analysis, Directorate General for Defense

Strategy, Ministry of Defense

- Brig. Gen. Hari Mulyono

Akmil 1983

Infantry

25 July 2011

Deputy Assistant for Army Personnel 
- Brig. Gen. Jaswandi

Akmil 1985

Infantry

10 June 2013

Deputy Commander General, Kopassus

Commander, Kodam IX/Udayana

(Major General)

- Maj. Gen. Hotmangaradja Pandjaitan

b. 14 October 1953

Akmil 1977

Infantry

29 May 2008

Assistant for Army Territorial Affairs

- Brig. Gen. Rahmat Budiyanto (promotion)

Akmil 1981

Field Artillery

25 March 2010

Chief of Staff, Kodam III/Siliwangi

- Maj. Gen. Leonard

Akmil 1981

Infantry

4 May 2011

Assistant for Army Security Affairs

- Maj. Gen. Wisnu Bawa Tenaya

b. 24 April 1958

Akmil 1981

Infantry

15 June 2012

Commander General, Kopassus

Chief of Staff, Kodam IX/Udayana

(Brigadier General)

- Brig. Gen. Agung Revulton

Akmil 1977

Infantry

October 2008

Deputy Assistant for Army Operations

- Col. Endar Priyanto (promotion)

Akmil 1981

Infantry

10 May 2010

Secretary, Dispenad

- Brig. Gen. Pratimun

Akmil 1982

Infantry

19 October 2011

Expert Staff to Kasad
- Brig. Gen. Danu Nawawi

Akmil 1981

Field Artillery

1 July 2013

Deputy Commander, Seskoad

Commander, Kodam XII/Tanjungpura

(Major General)

- Maj. Gen. Moeldoko

b. 8 July 1957

Akmil 1981

Infantry

10 May 2010

Commander, Infantry Division-1,

Kostrad

- Maj. Gen. Geerhan Lantara

b. 25 May 1956

Akmil 1978

Infantry

28 September 2010

Commander, Infantry Division-2,

Kostrad

- Maj. Gen. Erwin Hudawi Lubis

b. 7 August 1956

Akmil 1980

Infantry

19 October 2011

Commander, Pussenif

- Maj. Gen. M. Ridwan

Akmil 1981

Infantry

1 August 2012

Commander, Infantry Division-2,

Kostrad

- Maj. Gen. Ibrahim Saleh

b. 21 December 1957

Akmil 1983

Infantry

18 August 2013

Deputy, BAIS

Chief of Staff, Kodam XII/Tanjungpura

(Brigadier General)

- Brig. Gen. Armyn Ali Anyang

b. 5 February 1956

Akmil 1980

Infantry

10 May 2010

Deputy Assistant for Army Planning 
- Brig. Gen. Robby Win Kadir Akmil 1982

Infantry

17 October 2011

Expert Staff to Kasad

- Brig. Gen. Anang Sutisna

Akmil 1981

Infantry

18 August 2013

Inspector, Coordinating Ministry for

Politics, Law and Security Affairs

Commander, Kodam XVI/Patimura

(Major General)

- Maj. Gen. Muhammad Noer Muis

b. 22 August 1953

Akmil 1976

Infantry

13 November 2008

Chief of Staff, Kostrad

- Maj. Gen. Hatta Syarifudin

Akmil 1976

Infantry

11 January 2010

Commander, Infantry Division-1, Kostrad

- Maj. Gen. Suharsono

Akmil 1977

Cavalry

25 January 2011

Governor, Akmil

- Maj. Gen. Eko Wiratmoko

Akmil 1982

Infantry

24 September 2012

Assistant for Army Security

Chief of Staff, Kodam XVI/Patimura

(Brigadier General)

- Brig. Gen. Thomas Edy Widagdo

Akmil 1978

Field Artillery

$<$ July 2010

- Brig. Gen. Bambang Budi Waluyo

b. 19 November 1956

Akmil 1981

Infantry

4 May 2011

Expert Staff to Panglima TNI
- Col. Winston Simanjuntak (promotion)

b. 12 June 1957

Akmil 1981

Infantry

21 November 2011

Expert Staff to Chief of Staff, Kodam

XVI/Patimura

- Brig. Gen. Torry Djohar Banguntoro

b. 14 September 1957

Akmil 1982

Infantry

16 September 2013

Head, BIN Jakarta Office

Commander, Kodam XVII/Cendrawasih

(Major General)

- Maj. Gen. Azmyn Yusri Nasution

b. 26 March 1954

Akmil 1977

Infantry

30 June 2008

Commander, Infantry Division-2,

Kostrad

- Maj. Gen. Hotma Marbun

b. 10 May 1955

Akmil 1977

Infantry

17 November 2009

Assistant for Army Operations

- Brig. Gen. Erfi Triassunu (promotion)

Akmil 1978

Combat Engineer \& Topography

8 September 2010

Chief of Staff, Kodam Iskandar Muda

- Maj. Gen. Erwin Syafitri

b. 9 April 1959

Akmil 1982

Infantry

1 February 2012

Deputy, BAIS

- Maj. Gen. Christian Zebua

b. 24 October 1957

Akmil 1980

Combat Engineer (Zeni)

24 September 2012

Lecturer, Lemhannas 
Chief of Staff, Kodam XVII/Cendrawasih (Brigadier General)

- Brig. Gen. Osaka Meliala

Akmil 1977

Field Artillery

23 October 2009

Deputy Commander, Seskoad

- Brig. Gen. Indra Hidayat R.

Akmil 19??

Infantry

December 2010

- Col. Daniel Ambat (promotion)

Akmil 1983

Infantry

21 November 2011

Inspector, Kodam Jaya

- Brig. Gen. I Made Agra Sudiantara

b. 26 March 1962

Akmil 1985

Infantry

6 July 2012

Deputy Assistant for Army Operations

- Brig. Gen. Hinsa Siburian

Akmil 1986

Infantry

15 May 2013

Commander, Korem 173/Praja Vira

Braja, Kodam XVII/Cendrawasih

Commander, Kodam Jaya

(Major General)

- Maj. Gen. Darpito Pudyastungkoro

b. 31 August 1952

Akmil 1975

Cavalry

30 June 2008

Commander, Kodam IV/Diponegoro

- Maj. Gen. Marciano Norman

b. 28 October 1954

Akmil 1978

Cavalry

10 May 2010

Commander, Presidential Guards
- Maj. Gen. Waris

b. 12 December 1957

Akmil 1981

Infantry

1 March 2011

Commander, Presidential Guards

- Maj. Gen. Erwin Hudawi Lubis

b. 7 August 1956

Akmil 1980

Infantry

1 August 2012

Commander, Kodam XII/Tanjungpura

Chief of Staff, Kodam Jaya

(Brigadier General)

- Brig. Gen. Moeldoko

b. 8 July 1957

Akmil 1981

Infantry

June 2008

Director for Doctrine, Kodiklatad

- Brig. Gen. Waris

b. 12 December 1957

Akmil 1981

Infantry

11 January 2010

Expert Staff to Kasad

- Brig. Gen. Muhamad Munir

b. 28 October 1958

Akmil 1983

Infantry

10 May 2010

Chief of Staff, Infantry Division-1,

Kostrad

- Brig. Gen. Ibrahim Saleh

b. 21 December 1957

Akmil 1983

Infantry

28 September 2010

Commander, Pusintelad

- Brig. Gen. Edy Susanto

Akmil 1981

Infantry

4 May 2011

Chief of Staff, Jakarta Garrison 
- Brig. Gen. Agung Risdhianto

b. 22 April 1961

Akmil 1985

Infantry

1 August 2012

Deputy Commander, Pussenif

Commander, Kodam Iskandar Muda

(Major General)

- Maj. Gen. Soenarko

Akmil 1977

Infantry

29 May 2008

Commander, Kopassus

- Maj. Gen. Hambali Hanafiah

Akmil 1978

Infantry

23 October 2009

Chief of Staff, Kodam

XVII/Cendrawasih

- Maj. Gen. Adi Mulyono

Akmil 1981

Infantry

6 October 2010

Commander, Infantry Division-1, Kostrad

- Brig. Gen. Zahari Siregar (promotion)

b. 9 March 1957

Akmil 1980

Infantry

6 July 2012

Chief of Staff, Kostrad

- Brig. Gen. Pandu Wibowo (promotion) Akmil 1981

Infantry

18 August 2013

Deputy Commander, Sesko TNI

Chief of Staff, Kodam Iskandar Muda

(Brigadier General)

- Brig. Gen. Pandu Wibowo

Akmil 1981

Infantry

8 September 2010

Inspector for General Affairs, Itjenad
- Brig. Gen. Iskandar M. Sahil

Akmil 1982

Infantry

6 March 2012

Deputy Assistant for Army Territorial Affairs

- Brig. Gen. Suhastir Susmex

Akmil 1980

Infantry

24 September 2012

Inspector for General Affairs, Itjenad

- Brig. Gen. Purwadi Mukson

b. 21 February 1959

Akmil 1982

Cavalry

1 July 2013

Commander, Pussenkav

Commander, Korem 031/Wirabima

(Brigadier General)

- Brig. Gen. Teguh Rahardjo

Akmil 1981

Cavalry

5 May 2012

Expert Staff to Kasad

- Brig. Gen. Prihadi Agus Irianto R.

Akmil 1987

Infantry

18 August 2013

Director for Training, Kodiklatad

Commander, Korem 033/Wirapratama

(Brigadier General)

- Brig. Gen. Deni K. Irawan

Akmil 1983

Infantry

5 May 2012

Expert Staff to Kasad

- Col. B. Zuirman (promotion)

Akmil 1983

Infantry

1 July 2013

Inspector, Kostrad

Commander, Korem 072/Pamungkas

(Brigadier General)

- Brig. Gen. Adi Widjaya

Akmil 1983

Infantry

5 May 2012

Deputy Governor, Akmil 
- Col. Mohamad Sabrar Fadhilah (promotion)

Akmil 1988

Infantry

1 July 2013

Commander, Korem 143/Ho, Kodam

VII/Wirabuana

Commander, Korem 091/Aji Surya

Natakesuma

(Brigadier General)

- Col. Gadang Pambudi (promotion)

Akmil 1984

Infantry

5 May 2012

Commander, Student Corps, Seskoad

- Col. Nono Suharsono (promotion)

Akmil 1984

Infantry

16 September 2013

Secretary, Pusterad

Commander, Korem 131/Santiago

(Brigadier General)

- Col. Johny L. Tobing (promotion)

Akmil 1983

Infantry

5 May 2012

Expert Staff to Kasad

- Col. Musa Bangun (promotion)

Akmil 1983

Infantry

1 July 2013

Director for Doctrine, Kodiklatad

Commander, Korem 161/Wirasakti

(Brigadier General)

- Brig. Gen. Ferdinand Setiawan

Akmil 1983

Infantry

5 May 2012

Expert Staff to Kasad

- Col. Achmad Yulianto (promotion)

Akmil 198?

Infantry

24 September 2013

Deputy Commander, Secapaad
Commander, Korem 171/Praja Vita Tama

(Brigadier General)

- Brig. Gen. Pandji Suko Hari Yudho

Akmil 1983

Infantry

5 May 2012

Head, Dispenad

- Col. Djoko Subandrio (promotion)

Akmil 1983

Infantry

1 July 2013

Inspector, Itjenad

Commander, Korem 173/Praja Vita Braja

(Brigadier General)

- Col. F.X. Bangun Pratiknyo (promotion) Akmil 1985

Infantry

5 May 2012

Middle-rank officer, Spamad

- Col. Hinsa Siburian (promotion)

Akmil 1986

Infantry

24 April 2013

Director for Training, Kodiklat TNI

- Col. Chamim Besari (promotion)

Akmil 1983

Infantry

15 May 2013

Secretary, Pusterad

Commander, Korem 174/Anim Ti

Waninggap

(Brigadier General)

- Col. Edy Rahmayadi (promotion)

Akmil 1985

Infantry

5 May 2012

Middle-rank officer, Army HQ

- Brig. Gen. Bambang Haryanto

Akmil 1984

Infantry

16 September 2013

Director, Lemhannas 
